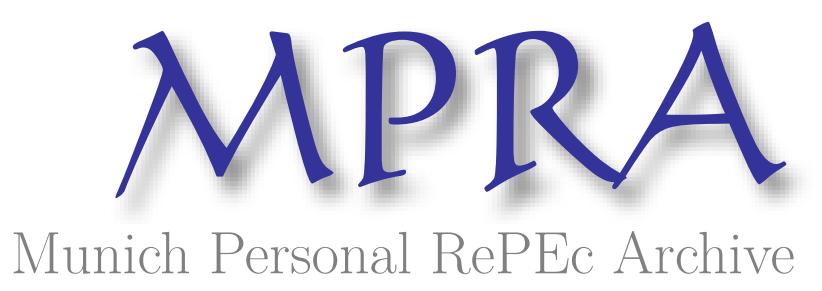

\title{
Broadening benefits from natural resource extraction: Housing values and taxation of natural gas wells as property
}

Weber, Jeremy G. and Burnett, J.Wesley and Xiarchos, Irene M.

Graduate School of Public and International Affairs, University of Pittsburgh, College of Charleston, U.S. Department of Agriculture

18 January 2016

Online at https://mpra.ub.uni-muenchen.de/68900/ MPRA Paper No. 68900, posted 20 Jan 2016 05:17 UTC 


\title{
Broadening Benefits from Natural Resource Extraction: Housing Values and \\ Taxation of Natural Gas Wells as Property
}

FORTHCOMING IN THE JOURNAL OF POLICY ANALYSIS AND MANAGEMENT

A prior version of this paper is: Weber, J.G., J.W. Burnett, and I.M. Xiarchos, 2014, "Shale Gas Development and Housing Values over a Decade: Evidence from the Barnett Shale" USAEE Working Paper No. 14-165.

Jeremy G. Weber*, J. Wesley Burnett ${ }^{\dagger}$, Irene M. Xiarchos

\begin{abstract}
We study the effects of the property tax base shock caused by natural gas drilling in the Barnett Shale in Texas-a state that taxes oil and gas wells as property. Over the boom and bust in drilling, housing appreciation closely followed the oil and gas property tax base, which expanded the total tax base by 23 percent at its height. The expansion led to a decline in property tax rates while maintaining or increasing revenues to schools. Overall, each $\$ 1$ per student increase in the oil and gas property tax base increased the value of the typical home by $\$ 0.15$. Some evidence suggests that the cumulative density of wells nearby may lower housing values, indicating that drilling could reduce local welfare without policies to increase local public revenues.
\end{abstract}

Keywords: Shale Gas; Property Taxes; Housing Values

JEL Codes: Q32, Q33, H71, Q51

*Assistant Professor, University of Pittsburgh, Graduate School of Public and International Affairs, 3601 Wesley W. Posvar Hall, Pittsburgh, Pennsylvania 15260, 412.648.2650, jgw99@ @itt.edu

$\dagger$ Assistant Professor, College of Charleston, Department of Economics, 5 Liberty Street, Beatty Center Suite 413, Charleston, SC 29424, burnettjw@cofc.edu

$\$$ Natural Resource Economist, U.S. Department of Agriculture, Office of Energy Policy and New Uses, Office of the Chief Economist, 1400 Independence Ave. SW, Washington, DC 20250-1800, 202.690.3592, ixiarchos@oce.usda.gov

The views expressed are those of the authors and should not be attributed to the U.S. Department of Agriculture. 


\section{INTRODUCTION}

Extraction of natural gas or other natural resources has been argued to improve economic outcomes in some regions of the country and not others. Oil abundance, for example, increased long-term per capita income in the south-central U.S. (Michaels, 2011), but extractive booms elsewhere in the country eventually lowered income (Jacobson \& Parker, 2014). What explains such diverse experiences? Variation in policy provides a potential explanation, with some policies turning periodic natural resource windfalls into benefits enjoyed more broadly into the future. An important policy difference across U.S. states is whether oil and gas wells are taxed as property and in turn fund schools, roads, and other local public investments that affect long-term economic performance and welfare. Some major oil and gas producing states have such taxes (Texas, and Colorado); others do not (Louisiana and Pennsylvania) (Raimi \& Newell, 2014).

We study Texas' Barnett Shale, which has the longest history of drilling of any shale formation in the world, and show how taxing natural gas wells as property shaped the relationship between shale development and housing values. There are good reasons to expect expansions in the property tax base to benefit local residents and increase housing values. In most states important public goods-roads, parks, and primary and secondary education-are provided locally and funded primarily through taxes on the value of real property. Tiebout's seminal 1956 paper envisioned people moving to areas with better schools, cleaner streets, and lower taxes, and later studies theoretically and empirically linked local public goods directly to housing values (Oates, 1969; Edel \& Sclar, 1974). Oates (1969) in particular found that people are willing to pay more for housing in areas with lower property tax rates and more school spending per student, two findings that subsequent studies have largely supported (Wassmer, 1993; Bradbury, Mayer, \& Case, 2001; Buettner, 2003; Barrow \& Rouse, 2004; Lang \& Jian, 2004). 
Despite the long-standing literature on local public finances and housing values, we are unaware of studies that explore the fundamental relationship between the property tax base, which may fund a variety of local amenities or tax relief, and housing values. This is likely because of the empirical challenge that it presents. The property tax base commonly consists of the value of residential property, commercial property, and undeveloped land. Because the values of all three are correlated, if the tax base expands in one area and not another, it is likely that housing values are already increasing faster in the area with the expanding tax base. An exception is when the property tax base includes a category of property whose value depends almost entirely on factors unrelated to the local real estate market. Such is the case with new natural gas wells in shale formations, whose existence and value depends on geology, industrywide technological innovation, and the national price of natural gas.

Innovations in technology and rising natural gas prices spurred a flurry of drilling in gasrich shale formations in the 2000s. Although geologists knew that shale formations around the U.S. contained much natural gas, the low permeability of the shale prevented cost-effective extraction. This changed with innovations in hydraulic fracturing, or fracking, which is a technique in which a mixture of water, sand, and other chemicals are injected at high pressure to fracture the rock (Environmental Protection Agency, 2011). Improvements in drilling horizontal wells, which better suited the thin shale strata, also made wells more productive. The widespread use of both technologies in tandem caused natural gas production in the U.S. to increase by approximately 35 percent over the 2005 to 2013 period (Aguilera \& Radetzki 2013).

The first place to experience large-scale drilling was Texas' Barnett Shale, which has had more wells drilled over a longer time and in a smaller area than any other shale formation in the world. Because natural gas wells are taxed as property in Texas, the drilling created a rapid 
expansion in the property tax base. This presents an empirical opportunity to study the link between the property tax base and housing values, especially considering that the Barnett Shale conveniently splits the Dallas-Fort Worth area in half, with all drilling occurring on the western side and none occurring on the eastern side (Figure 1). The clear geological demarcation of shale and nonshale areas, all within the Dallas-Fort Worth regional economy, permits transparent comparisons and aids in separating the effect of development from confounding factors. Variation in geology within the shale area that is correlated with drilling intensity provides further variation for statistical analysis.

Our study looks at zip code level housing values from 1997 to 2013 . The study period covers a decade of development: drilling started in the early 2000s, peaked in 2008, and by 2013 had slowed to the level observed in 2001. This particular study of the Barnett Shale departs from existing studies of shale development on housing values (Gopalakrishnan \& Klaiber, 2013; Muehlenbachs, Spiller, \& Timmins 2012, 2015; Boslett, Guilfoos, \& Lang, 2015), which focus on Pennsylvania-a state that excludes oil and gas wells from property taxes. Consequently, development would have no clear effect on housing values via the tax base, and the authors understandably omit discussion of how public finance policy may shape the welfare consequences of shale development.

We find that taxing of oil and gas wells as property led to systematic increases in housing values, with shale zip codes retaining a 9 percent advantage in housing values relative to nonshale zip codes in 2013, well after drilling had slowed. Housing values closely followed changes in the oil and gas property tax base, with each $\$ 1$ per student increase in tax base associated with a $\$ 0.15$ increase in the value of the typical house. The expansion in the tax base was also associated with marginally higher revenues for schools and a nine percent decrease in 
the property tax rate levied by school districts. Holding the tax base constant, we also find some evidence that the cumulative number of wells drilled nearby lowered housing values, indicating that shale development may reduce local resident welfare in the absence of policies to increase local public revenues.

\section{CONCEPTUAL FRAMEWORK}

Resource extraction can affect public finances and therefore tax rates and public spending (Caselli \& Michaels, 2013; Raimi \& Newell, 2014). All else constant, an expanded tax base brought about by extraction should allow local governments to provide more public services or lower tax rates or both. This should make people more willing to live in the area and raise housing values.

If elected authorities maximize the utility of the median voter, they will use the potential revenues from the expanded tax base to provide public services and lower tax rates such that the resident's marginal utility of a dollar more in public services equals that of a dollar less in taxes. Preferences for particular public goods, or any public good, versus lower tax rates can vary across space. Ample research shows that the demographics of the median voter affect the demand for particular policies (Bergstrom \& Goodman, 1973; Poterba, 1997; Courant \& Loeb, 1997; Binet, 2013). Poterba (1997), for example, finds that jurisdictions with a greater share of elderly residents are associated with significant reductions in per-child educational spending. Similarly, if voters believe that additional spending on education will not improve educational quality (e.g. Hanushek, 1981), they may demand that revenues be spent elsewhere or distributed to them through lower tax rates. 
Another motivation for residents preferring lower tax rates is that the state government may sequester some of the additional revenues through a revenue equalization program, which states (such as Texas) have for school funding. In this case, part of the marginal dollar in tax revenue is exported to property-poor areas, motivating property-rich areas to lower tax rates and reduce the revenues that are reallocated by the State government (see Foster and Fowles (2014) for an example of incentives for states to export tax burdens for education spending to the Federal government).

In addition to bringing greater public spending or property tax relief, the source of the tax base expansion may also bring disamenities and general public costs. This is particularly salient for shale gas development. Public perception in the state of New York is such that residents are willing to pay higher electricity prices to avoid shale development (Popkin et al, 2013). One well can involve hundreds of truck trips for each well, creating noise and reducing air quality (Kargbo, Wilhelm, \& Campbell, 2010; Litovitz et al., 2013). This can in turn degrade infrastructure and affect human health (Hill, 2013; Abramzon et al., 2014). The degradation of roads and bridges from increased truck traffic would require public spending for restoration. Similarly, local governments may incur costs to ameliorate disamenities or enforce protective measures like buffer zones or fences between gas infrastructure and residences.

How much a tax base expansion is capitalized into housing values reflects in part how much it funds restorative or protective measures, which seek to merely maintain amenities, rather than funding improvements in amenities or reductions in tax rates. For example, the truck traffic association with drilling might double the public road expenditures needed to maintain a certain stock of roadway. If the costs of drilling, broadly understood, exceed the revenues that it 
generates, there may even be negative relationships between the oil and gas tax base and housing values.

The rate of capitalization also reflects expectations about the persistence of the tax base expansion and the effectiveness of public management of additional revenues. Prospective homebuyers will pay a smaller premium if they expect higher public revenues to last only a few years. Similarly, buyers are unlikely to pay more for a house in an area with a large tax base if the revenue generated by it is spent poorly. The cross-country literature on natural resources has many examples of poorly managed windfalls and eroded institutions (Van der Ploeg, 2011). Within-country evidence also exists-Caselli and Michaels (2013) found that the flow of public goods and services observed in Brazilian municipalities was smaller than expected given their large oil revenue windfalls, suggesting what they termed as "missing money."

\section{Hypothesized Relationships Guiding the Empirical Analysis}

Figure 2 depicts the hypothesized relationships between drilling, local public finances, and housing values. Prior to drilling, the property tax base consists of non-oil and gas property; namely land, residential property, and commercial property. With a boom in drilling, the value of wells constitutes oil and gas property wealth and expands the total property tax base. The expanded tax base, in turn, could cause a decline in tax rates, an increase in school funding, or an increase in public amenities such as parks and libraries. Any one of these changes should make the locality a more attractive place to live and increase housing values. Though not shown, we also note that changes in housing values could eventually change the residential property tax base and in turn the total property tax base and local public finances. This potential reinforcing 
feed-back effect is still rightly attributed to the initial change in the oil and gas tax base and may be captured by an empirical analysis over a longer time frame.

The arrow directly linking drilling to housing values reflects the possibility that disamenities from drilling such as increased noise and traffic could reduce housing values. Unless such disamenities are controlled for, the empirical relationship between oil and gas property wealth and housing values would reflect the positive effect of the tax base expansion with the negative effect of drilling disamenities.

Though not shown, drilling may affect housing values through several other channels. By increasing economic activity, it may affect the value of land or commercial property and ultimately housing values. Or, an increase in labor demand and therefore housing demand could also raise values. Lastly, housing values might increase because of the rising value of natural gas rights attached to residential property. We empirically examine all three possibilities in later sections.

\section{BARNETT SHALE DEVELOPMENT}

The Barnett Shale lies in northeastern Texas, with its eastern boundary splitting the Dallas-Fort Worth metropolitan region in half. Drilling companies in the Barnett Shale led the advancement of hydraulic fracturing and horizontal drilling (Rahm, 2011). Mitchell Energy pioneered experimentation with hydraulic fracturing in the Barnett in the 1990s with mixed success. But by 2001 refinements in fracking and its combination with horizontal drilling began yielding fruit. In the following years the industry's widespread skepticism of the Barnett evaporated as natural gas prices increased and more than justified the higher cost of fracking and drilling horizontal wells (Zuckerman, 2013). 
The Barnett Shale zip codes used in this study show very little drilling activity in the 1997 through 2000 period, with less than 200 wells drilled each year (Figure 3). Drilling increased throughout the early 2000s and peaked in 2008 when nearly 1,800 wells were drilled. With the drop in natural gas prices in 2009 , drilling fell by more than a half. The decline continued, with fewer wells drilled in 2013 than in 2000. Texas Railroad Commission (2015) data on drilling permits and production for the entire Barnett Shale show a similar pattern. Because production lags drilling, total natural gas production from the Barnett peaked in 2012 and declined afterwards (Texas Railroad Commission, 2015).

\section{Oil and Gas Property Assessment and Taxation}

In Texas, oil and gas wells enter the property tax base once production begins. Private assessors, contracted by counties, value each well by estimating the present value of income that it will generate given projected production and prices. Values are reassessed annually to reflect new information, such as changes in prices. Unsurprisingly, as drilling expanded in the Barnett, the

average oil and gas property tax base in shale zip codes increased by roughly $\$ 85,000$ per student over nine years, which represents an nearly $25 \%$ increase over the total property tax base for the average zip code in 2000 (Figure 3, right axis). The oil and gas tax base then declined substantially in 2011 and continued declining in 2012 and 2013. The one-year lag between the decline in drilling and the decline in the oil and gas tax base reflects the lag between when a well is drilled and its first assessment.

In Texas, energy companies pay the majority of property taxes on oil and gas wells. Separate taxes are paid by the entities with a royalty interest (i.e. the owner of the oil and gas rights) and the entities with a working interest (i.e. the energy company) in the well. Suppose 
that the owner of the oil and gas rights within a parcel (who may or may not own the parcel's surface) leased the parcel to an energy company for a 12.5 percent royalty rate, and the company subsequently drilled a well. The owner would pay property taxes on 12.5 percent of the well's value, and the company would pay taxes on the remaining 87.5 percent. ${ }^{1}$ Because royalty rates are typically below 25 percent (Brown, Fitzgerald, Weber, 2015), the energy company pays the majority of taxes associated with the well, though some of the burden may pass-through to subsurface owners through lower royalty rates.

\section{DATA AND SAMPLE}

Our full sample contains all the zip codes in the Dallas-Fort Worth region where less than 75 percent of the area was urban as defined by the 2000 Census and where Zillow housing data are available over the years 1997 to 2013 . We focus on semi-urban or suburban zip codes because that is where most drilling occurred. The focus also helps to create a more homogenous sample since inner-city zip codes likely have different housing markets and public finance dynamics than more suburban zip codes.

The full sample has 79 zip codes, with 37 shale zip codes and 42 nonshale zip codes. Shale zip codes are defined as those entirely within the Barnett Shale, while nonshale zip codes are those entirely outside of the Barnett. Defining zip codes in this way-as opposed to a measure of drilling activity-ensures that the classification is based entirely on an exogenous characteristic (the underlying geological formation) and not endogenous factors such as drilling decisions. Moreover, widespread drilling occurred across shale zip codes, with only a few zip codes having few or no wells. This can be seen in Figure 4, which shows shale and nonshale sample zip codes,

\footnotetext{
${ }^{1}$ Details on oil and gas property tax assessment in Texas are available at www.isouthwestdata.com/client/downloads/wisecad/APPRAIS AL/Mineral\%20Appraisal\%20Handout.pdf
} 
the eastern boundary of the shale formation, and the location of wells drilled between 2000 and 2013.

We use the zip code-level Zillow Home Value Index (ZHVI) as our measure of housing values. Prior studies of housing values have used Zillow data, including Sanders (2012) and Huang and Tang (2012). The ZHVI is Zillow's estimate of the median value of single-family residences, condominiums, and cooperative housing in the specified area. The estimate is based on information from properties collected from public records, including sale price and home characteristics. The appendix further describes the ZHVI and compares it with the widely known S\&P/Case-Shiller Home Price Index. ${ }^{2}$ In addition to the ZHVI being publically available and having desirable properties as an index, the S\&P/Case-Shiller Home Price Index is not available at the zip code-level in Texas.

As illustrated in Figure 2, shale development likely affects housing values through its effects on local public finances. We consider four finance-related variables: (1) the oil and gas property tax base; (2) the tax base excluding oil and gas and residential property; (3) the school district property tax rate; and, (4) school district revenues. The tax base, excluding oil and gas and residential property, consists of the assessed value of undeveloped land, commercial property, and a small residual "other" category.

To account for variation in population across zip codes, all variables except the tax rate are per enrolled student. The tax base and school revenue data are from the Texas Education Agency; the Texas Bond Review Board reports the property tax rate. The data are available starting in 2000. All variables are allocated from the school district-level to the zip code-level based on the share of the zip code in each particular school district. More than three-quarters of

\footnotetext{
${ }^{2}$ All appendices are available at the end of this article as it appears in JPAM online. Go to the publisher's website and use the search engine to locate the article at http://www3.interscience.wiley.com/cgibin/jhome/34787.
} 
the area of the typical zip code lies in just one school district. Appendix section A.2 further describes the sources and creation of these variables. The school finance data cover the 2000 to 2013 period.

Some of the empirical models also employ data from three additional sources. Highresolution spatial data on shale geology (thickness and depth) come from the Los Alamos National Laboratory. The timing and number of wells drilled in a zip code are based on well data from DrillingInfo, a provider of proprietary data on oil and gas leasing and drilling. In addition, we use national wellhead natural gas prices from the U.S. Energy Information Administration.

Table 1 provides the means for the public finance variables for shale and nonshale zip codes for the year 2000. All monetary values are in constant 2010 dollars. The average zip code had a property tax base of $\$ 350,000$ per student, with residential property accounting for roughly half of the base. The schools in the average zip code had a property tax rate of 1.54 percent, had nearly 19,000 students, and received $\$ 9,300$ in revenue (from all sources) per student. Comparing means across shale and nonshale zip codes reveals that shale zip codes, on average, had a slightly larger tax base and a higher tax rate while both groups had similar revenues per student and similar residential property tax bases.

From Table 1 we also see that shale zip codes had minimal drilling activity in 2000 , with only 0.03 wells drilled per square kilometer. That changed over the following 13 years, with the cumulative number of wells drilled in average shale zip codes reaching 1.94 wells per square kilometer in 2013. Nonshale zip codes, in contrast, had essentially no wells drilled over the period. Table 1 also shows that shale and nonshale zip codes had statistically similar levels and growth rates in housing values prior to large-scale shale development. For the four years from 1997 to 2000 , the average annual ZHVI was $\$ 151,800$ for shale zip codes and $\$ 148,700$ for 
nonshale zip codes. Moreover, the growth rates in the ZHVI were essentially identical, at three percent.

\section{METHODS}

Our empirical analysis consists of first documenting how average differences across shale and nonshale zip codes evolved over time for key variables. Then we directly link changes in the oil and gas tax base to housing values using an instrumental variable approach.

\section{Dynamic Shale Effects on Housing Values and Local Public Finances}

We estimate how housing values evolved over time and across zip codes in and out of the shale using,

$$
\text { ZHVI }_{i t}=\theta_{i}+\left(\text { Shale }_{i} \boldsymbol{Y}_{t}^{\prime}\right) \boldsymbol{\beta}+\boldsymbol{Y}_{\boldsymbol{t}} \boldsymbol{\alpha}+\varepsilon_{i t},
$$

where the ZHVI is either in levels or in $\log$ form and $\theta_{i}$ is a zip code fixed effect. $\boldsymbol{Y}_{\boldsymbol{t}}$ is a vector of year binary variables, corresponding to the years 1998 to 2013, with 1997 being the excluded year. Shale is a binary variable indicating that a zip code is in the shale. It does not enter the regression by itself because it is time invariant and is therefore absorbed by the zip code fixed effect. However, the coefficients on the interaction between Shale and the year binary variables ( $\boldsymbol{\beta})$ show how housing values evolved differently for shale and nonshale zip codes, conditional on the zip code fixed effect.

The same estimation approach is taken to explore changes in local public finances. The only difference is that the public finance variables are available starting in 2000, so the excluded year dummy variable corresponds to 2000 instead of 1997. 
The shale binary variable is based entirely on the geological attributes of the zip codes and is therefore exogenous to human action. It is possible that a time-varying shock unrelated to shale development affected shale and nonshale zip codes differently, and we consider potential confounding shocks in a later section. In absence of such a shock, the shale variable captures the evolving average effect of shale development on housing values and local public finances.

\section{Capitalization of the Oil and Gas Tax Base into Housing Values}

As Figure 2 highlights, housing values depend on tax rates and the provision of public goods, which in turn depend on the tax base. Consider a model linking housing values in time $t$ to the level of the oil and gas tax base in the prior year while controlling for a zip code and time fixed effect:

$$
Z H V I_{i t}=\theta_{i}+\alpha_{t}+\beta \cdot O G \text { Tax }_{\text {Base }}{ }_{i t-1}+\varepsilon_{i t}
$$

where $\theta_{i}+\alpha_{t}$ are zip code and year fixed effects and $O G$ Tax Base is the oil and gas tax base ( $\$ 10,000$ per student) in the prior year. The lagged change in the tax base is used because tax assessments in one year provide revenues for the following year. Differencing (2) from one period to the next removes the zip code fixed effect:

$$
\Delta Z H V I_{i t}=\Delta \alpha_{t}+\beta \cdot \Delta O G \operatorname{Tax} \text { Base }_{i t-1}+\Delta \varepsilon_{i t}
$$

where the change in the year fixed effects can be captured by dummy variables corresponding to year pairs, with the 2000-2001 year-pair excluded.

If the ZHVI is defined in units of $\$ 10,000$, the coefficient on the change in the oil and gas tax base gives the dollar-value change in the value of the typical home for each dollar increase in the oil and gas tax base per student. If the change in the natural logarithm of the ZHVI is the 
dependent variable, the coefficient gives the percent change in housing values for a $\$ 10,000$ per student increase in the oil and gas tax base.

Equation (3) is estimated in two ways. The first way exploits annual variation in the oil and gas tax base, where $\Delta$ refers to the change from one year to the next (e.g., 2000 to 2001). This particular specification assumes that housing markets quickly capitalize changes in the tax base. The second approach exploits the net change from 2000 to 2013 by converting the dataset into a cross-section of differences by subtracting the 2000 housing value from the level in 2013 (or, for the lagged change in the oil and gas tax base, subtracting 2000 from 2012). Using the change from 2000 to 2013 permits capturing capitalization that occurs over several years. It may also capture the effect of temporary increases in the tax base in the intervening years. An expansion that lasted only three years, for example, may have generated revenues that funded one-time improvements like new equipment at playgrounds, whose effect on housing values would likely persist.

\section{Identification of the Extent of Capitalization}

By only using changes in the oil and gas tax base and not changes in the total tax base, the specification in (3) avoids reverse causality because there is no plausible channel for housing values to affect the oil and gas tax base in the way that housing values affect the total tax base, which includes the assessed value of residential property. Nevertheless, changes in the oil and gas tax base reflect the leasing and drilling decisions of energy companies (and the owners of oil and gas rights) and may be correlated with housing appreciation. Moreover, the oil and gas tax base is possibly measured with error. If substantial, measurement error would attenuate the coefficient on the oil and gas tax base towards zero. 
Weber $(2012,2014)$ uses the location of unconventional natural gas formations to instrument for growth in natural gas production. Other studies have used similar resource-based measures and their interaction with changing market conditions, either as instruments or to estimate reduced-form equations similar to equation (1). These studies include Black et al (2005a, b) (coal dependence and coal prices), Angrist and Kugler (2008) (coca cultivation and coca prices), Michaels (2011) (oil endowments and time effects), Marchand (2012) (energy extraction dependence and price shocks), and Marchand and Weber (2015) (shale depth and oil and natural gas prices).

To address the endogeneity of drilling decisions and measurement error, we build on this approach by specifying the oil and gas tax base for equation 3 as a function of geology and the price of natural gas. Consider the model

$$
\text { OG Tax } \text { Base }_{i t}=\theta_{i}+\alpha_{t}+\gamma\left(\text { Geology }_{i} \cdot \ln \left(\text { Price }_{i t-1}\right)\right)+\mu_{i t}
$$

where Geology is a time-invariant measure of the geological attractiveness of drilling in particular zip code and Price $_{i t-1}$ is the lagged price of natural gas at the wellhead. (The lagged price is used because well valuations are finalized by January $1 \mathrm{st}$ and will reflect the conditions of the prior year (Texas Legislative Council, 2002)).

Differencing equation (4) across years yields the following:

$$
\Delta O G \operatorname{Tax}_{\text {Base }_{i t}}=\Delta \boldsymbol{\alpha}_{t}+\gamma\left(\text { Geology } \cdot \Delta \ln \left(\text { Price }_{i t-1}\right)\right)+\Delta \mu_{i t}
$$

Differencing removes the zip code fixed effect, but not the term involving time-invariant geology because it is interacted with the price of natural gas, which changes over time and affects the incentive to drill. 
The interaction between geology and natural gas prices provides a natural instrument for changes in the oil and gas tax base. To serve as an instrument, the variable must be statistically related to the variable it is instrumenting for, a condition commonly referred to as instrument relevance. Our proposed instrument should be relevant because higher prices should encourage more drilling and more so in areas with better geology. More wells, in turn, will increase the oil and gas tax base. The instrument must also be exogenous, in that the covariance between it and the error term in the second stage equation (equation 3) is zero. The exogeneity assumption can be further broken into two assumptions: 1) the instrument is randomly assigned and is therefore unrelated to omitted variables and 2) the instrument only affects the outcome through the stated channel (in this case, the oil and gas tax base), a condition often referred to as an exclusion restriction (see Imbens, 2014a).

While random assignment of prices and geology is plausible, the exclusion restriction may not hold. Better geology and higher prices encourage drilling, which may affect housing values through channels other than the tax base. (Other potential causal channels, such as the capitalization of the rights to revenues from natural gas production are considered in a later section). Most notably, drilling could create disamenities that reduce people's willingness to live in a particular neighborhood. This motivates us to control for the number of wells drilled per square kilometer in the zip code in the last two years (labeled Wells drilled/sq. $\mathrm{km}, \mathrm{t}, \mathrm{t}-\mathrm{l}$ ). We combine wells drilled in the current and prior year ( $t$ and $t-1)$ into one variable because they are highly correlated (correlation of 0.8 ), and wells drilled in the prior year may actually be hydraulically fracked in the current year, which is when it will generate the most disamenities. To capture the effect of persistent disamenities, we also control for the cumulative number of wells drilled per square kilometer in all years before then (Cumulative wells drilled/sq. $\mathrm{km}, \mathrm{t}-2$ ). 
We note that annual well drilling and housing value data may poorly capture short-term disamenity effects that last only a few months. Including well density variables, nonetheless, controls for any effect of drilling on the value of the typical home in the zip code, which is what is needed to avoid confounding disamenity and tax base capitalization effects.

Controlling for the number of wells drilled, however, brings its own challenges. Drilling is potentially endogenous to housing values in the same way that the oil and gas tax base might be endogenous. We therefore estimate equation (3) and the corresponding first stage in equation (5) with and without the well density variables.

For our instrumental variable approach, we consider three different measures of geological richness at the zip code level: shale thickness, shale depth, and the thickness-to-depth ratio. The thicker the shale the more natural gas it holds, allowing one horizontal well to draw more gas from its subterranean surroundings (Rokosh et al., 2009). Across the major U.S. shale plays, Brown, Fitzgerald, and Weber (2015) show that wells in areas with greater shale thickness have greater production. For the Barnett in particular, Browning et al. (2013) found that wells in thicker parts of the shale had greater productivity. Shale depth also matters, with wells in deeper shales having greater productivity but also greater costs (Kaiser \& Yu, 2014). The shale thickness-to-depth ratio combines both attributes. To aid in interpretation, we normalize the ratio by average thickness-to-depth ratio for shale zip codes (which have a positive value for the ratio).

We regress the cumulative number of wells drilled per square kilometer from 1997 to 2013 on a constant and each geological measure separately (results not shown). The thickness-todepth ratio had the strongest correlation with drilling. A thickness-to-depth ratio twice as large as 
that of the average shale zip code is associated with 2.7 more wells per square kilometer (standard error of 1.3). The thickness-to-depth ratio also had the strongest correlation with growth in the oil and gas property tax base.

Normalizing the thickness-to-depth ratio makes it easier to interpret our first stage results. The normalization yields a ratio value of one for a zip code with a thickness-to-depth that is equal to the average geology of shale zip codes. The coefficient $\gamma$ in (5) therefore gives the increase in the oil and gas tax base for a one percent increase in the price of natural gas, conditional on having the geology of the average shale zip code.

For estimation using annual changes, we present robust standard errors clustered by zip code. For the estimation using the change from 2000 to 2013, where each zip code appears only once, we present unclustered, robust standard errors. We used Stata 14 for the regression analysis, with instrumental variable estimates based on the "ivreg2" user-written program.

\section{RESULTS}

\section{Dynamic Shale Effects on Housing Values and Local Public Finances}

Figures $5 \mathrm{a}-5 \mathrm{f}$ depict the coefficients on the interaction between the shale binary variable and the year dummy variables from equation (1), with the dashed lines representing 95 percent confidence intervals. Looking at the log of the ZHVI, shale and nonshale zip codes had housing values that were statistically indistinguishable from each other during the early 2000s (Figure 5a). But from 2005 to 2013, shale zip codes had higher average values, with the difference peaking in 2011 and dropping substantially in 2012 and 2013. By 2013, shale zip codes retained a nine percent advantage in housing values. We observed a similar pattern when looking at the ZHVI in dollars (10,000s) (Figure 5b). 
The increase in housing values in shale zip codes occurred as the oil and gas tax base expanded dramatically. Compared to nonshale zip codes, the fixed effects model shows that the oil and gas tax base expanded by about $\$ 80,000$ per student from 2000 to 2009 (Figure 5c). To put the increase in perspective, it represents 23 percent of the average total tax base, which includes all property categories, in 2000 . In contrast to the oil and gas property tax base, Figure $5 \mathrm{~d}$ shows that shale and nonshale zip codes experienced similar changes in the tax base when excluding residential and oil and gas property. This result alleviates concerns about other confounding economic factors, indicating that shale zip codes did not experience different economic trends-in so much as those trends affect the value of commercial property or land. Had the drilling boom disproportionately affected business growth in the shale area, we would expect an expansion in the commercial property tax base relative to the nonshale area. Figure $5 \mathrm{~d}$ shows that this did not occur.

As the tax base expanded, school districts in shale zip codes lowered property tax rates (Figure 5e). By 2006 tax rates in shale zip codes had declined by nine percent decline relative to nonshale zip codes. Throughout the 2006 to 2013 period, the difference in tax rates was roughly constant, with the average shale zip code having a school property tax rate about 0.11 to 0.13 percentage points lower than the average nonshale zip code.

The increase in the tax base more than offset the decline in school tax rates, allowing school revenues to increase slightly, though the difference was statistically significant (at the ten percent level) only in 2009, with schools in shale zip codes receiving roughly $\$ 350$ more per student (Figure 5f). It appears that school districts first responded to the expanded tax base by lowering property tax rates. By 2006 most of the decline in tax rates had occurred. With the tax rate roughly constant after 2006 , the expansion in the tax base implied additional revenues for 
schools. But with steady tax rates in the later part of the study period, the eventual decline in the tax base unsurprisingly led to a decline in school revenues.

Besides the decline in property tax rates, one reason why the large increase in the tax base translated into a small increase in school revenues is because of school funding policy in Texas, which guarantees a certain level of funding per student. Districts whose property tax wealth is insufficient to generate this level receive additional funding from the state; districts with more than sufficient property wealth have some of their revenues captured and shared with less affluent districts. As such, a district that experiences an increase in property tax wealth would receive fewer transfers from the state and, if the district were sufficiently wealthy, some of its revenues would be recaptured by the state (TTARA, 2012). In this manner the policy limits the transmission of property wealth increases into local school revenues.

Figure 6 combines two key results: the relationship between a zip code's shale status and changes in the oil and gas tax base and shale status and changes in housing values. Housing values closely track growth in the oil and gas tax base, with a lag of one or two years.

\section{Capitalization of the Oil and Gas Tax Base into Housing Values}

The first stage equation (5) is estimated using annual changes in the tax base and the change from 2000 to 2013. The model based on annual changes indicates that a one percent increase in the price of natural gas leads to a roughly $\$ 30$ per student increase in the oil and gas tax base for a zip code with the average thickness-to-depth ratio among shale zip codes (Table 2). Regardless of whether the density of wells is controlled for, the $F$-statistic remains large enough to dismiss concerns about weak instrument bias (18.0 and 19.2). 
Using the change from 2000 to 2013 gives a coefficient of a different sign on the geology-price interaction. This is expected given the decline in real natural gas prices over the period, meaning that zips codes with better than average geology had larger negative values of the interaction term, but because of the better geology they also had larger increases in their tax bases, causing the negative correlation. Specifically, conditional on a one percent decrease in the price of natural gas, the oil and gas tax base increased by $\$ 60$ per student for the average shale zip code and by $\$ 28$ when controlling for well density. The corresponding $F$-statistics were 19.8 and 5.4, indicating sufficient instrument strength when not controlling for well density.

We estimate the second-stage equation (3) using OLS and the instrumental variable approach. For each estimation type, we present results for the logged and non-logged ZHVI and with and without controlling for well density. We also present the results based on annual changes (Panel A of Table 3) and based on changes over the 2000 to 2013 period (Panel B of Table 3).

The estimates from the annual IV approach indicate that a $\$ 10,000$ increase in the oil and gas tax base per student increases housing values by 0.6 percent (significant at the 10 percent level) (Table 3). In levels, each one-dollar increase in the tax base led to a roughly $\$ 0.15$ increase in housing values (significant at the five percent level). As expected with measurement error in the oil and gas tax base, the OLS results are about a third smaller in magnitude, though they are more precisely estimated. Controlling for well density slightly increases the IV point estimates but with marginally larger standard errors.

Using the change over the 2000 to 2013 period tends to give larger estimates of capitalization. We note that the IV results in the columns 4 and 8 of Panel B (Table 3) are associated with a weak first stage and likely suffer from weak instrument bias. Those estimates 
aside, the IV estimates when not controlling for well density (columns 3 and 6) indicate that a $\$ 10,000$ increase in the oil and gas tax base per student increases housing values by 1.7 percent (significant at the 5 percent level). In dollar terms, the estimates are similar to the annual-based estimates, with each one-dollar increase in the tax base leading to a $\$ 0.15$ increase in housing values (significant at the 10 percent level). The average shale zip code experienced a $\$ 43,500$ increase in the oil and gas property tax base per student from 2000 to 2012. All else constant, this implies an increase in housing values of 7.4 percent or $\$ 6,525$.

The coefficient on the density of wells drilled in the current or prior period varies in sign and is always statistically insignificant. The cumulative density of wells drilled shows a more consistent pattern of decreasing home values, though these estimates tend to have large standard errors and be statistically indistinguishable from zero. The most precisely estimated effect is that a one-unit increase in the lagged cumulative number of wells drilled decreases housing values by $\$ 320$ (significant at the one percent level). By 2011, the average shale zip code had a cumulative well density of 1.85 wells, implying a nearly $\$ 600$ dollar decrease in housing values from 2012 to 2013. Because wells persist for many years, this effect of cumulative well density could continue to exert downward pressure on housing values over time. Our measure of cumulative wells, however, does not drop wells as they age. At some point, possibly at the capping of a well, the disamenity effect of old wells likely goes to zero.

One explanation for a negative effect of past wells drilled is that people wait until drilling has subsided to sell their homes, delaying when the externalities are reflected in the ZHVI. Alternatively, companies frequently restimulate (or "refrack") older wells for additional production. Having more wells drilled in prior years would then be associated with more refracking - and therefore more truck traffic and noise - in the present. 


\section{Making Sense of the Capitalization Estimates}

Our annual estimate of capitalization indicates that a one-dollar per student increase in the oil and gas tax base is associated with a $\$ 0.15$ increase in the typical housing value. Is this plausible? Consider the present value of the discounted flow of public revenues from the expansion. Over the study period the average tax rate for properties in shale counties was $2.37 \%$, including school and community college taxes, city taxes, and county taxes. A dollar more in tax base per student therefore generates $\$ 0.0237$ in public revenues per year per student. Because the number of students roughly equals the number of housing units according to the 2000 Decennial Census, the same revenue increase applies to each housing unit.

If local officials manage revenues to maximize resident utility, the typical resident values a marginal dollar in public income the same as private income. The discount rate that equalizes a present value of $\$ 0.15$ with an infinite stream of payments of $\$ 0.0237$ is 16 percent $(=0.0237 / 0.15)$. The implied discount rate is plausible. Uncertainty over the persistence of the tax base expansion would cause homeowners to have a higher discount rate. In the extreme, the homeowner would assume that payments (in the form of tax savings or as greater public services) cease after several years. This is consistent with an expectation that the rate of drilling and the taxable value of existing wells will decline over time. In addition to the cessation of payments, some of the revenues raised are likely spent addressing public costs associated with the industry and are therefore unavailable to be passed on as tax savings or to fund additional public services.

\section{ROBUSTNESS ACROSS SAMPLES}




\section{Creating More Homogenous Subsamples}

Although assignment of zip codes to shale and nonshale groups is based on geology, some shale zip codes may have characteristics unlike that of any nonshale zip code. These initial differences in turn may have affected the evolution of housing values during the study period. We therefore define two subsamples where shale and nonshale zip codes are arguably more comparable than in the full sample.

The first subsample improves comparability based on initial socio-economic characteristics. Limiting the analysis to treatment (shale) and control (nonshale) observations with similar characteristics can make causal inference more robust, accurate, and efficient (Ho et al., 2007; Crump et al., 2009). As Imbens (2014b) shows, linear regression methods can give excessive influence to treatment observations in an area of the covariate space lacking control observations or vice versa. This has motivated researchers to estimate and use the propensity score-the probability of treatment, in this case the probability of being a shale zip code, given a set of observed covariates (Rosenbaum and Rubin, 1983)-to systematically select a sample as a precursor to regression (Angrist \& Pischke, 2009).

A perfect predictor of being a shale zip code is an indicator variable for being in the shale, but using only socioeconomic variables to estimate the propensity to be a shale zip code captures differences other than geology. Because the propensity score is a one-dimensional summary of observable differences between shale and nonshale zip codes, trimming on it removes shale zip codes that are substantially different from any nonshale zip code and vice versa, thereby improving comparability. 
We use 14 socioeconomic and housing-related variables from the 2000 Census to estimate the propensity score on the full sample of zip codes. Each one of the fourteen variables enters linearly into a bivariate Probit model. The variables employed include demographic variables (share of the population that is white, the share in three different age groups, the share with some college education), income variables (the share of the population in three different household income categories, median household income), urbanization variables (the percent of the zip code in an urban area, population density) and real estate variables (the percent of vacant housing units, the median year built, median real estate taxes). These are common control variables in housing value studies: Schwartz and Zorn, 1988 (population density and age demographics); Santiago et al., 2001 (real estate taxes and income); Ellen and Voicu, 2006 (proximity indicators); Di et al., 2010 (racial demographics); Bifulco, 2012 (age and racial demographics). Clearly, other factors affect housing values, but as previously mentioned, identification of the oil and gas tax base capitalization comes from spatial variation in geology and temporal variation in natural gas prices, both of which should be unrelated to local housing market shocks (excluding those related to shale development).

To trim the sample based on the propensity score, Crump et al. (2009) and Imbens (2014b) provide a data-driven method to calculate optimal cutoffs. The cutoffs are based on the asymptotic efficiency bound of the average treatment effect, which will presumably have greater variance in areas of the covariate space with a large disparity in the number of treatment versus control observations. We calculate the optimal cutoff for the propensity score by finding the cutoff that minimizes the function specified in Imbens (2014b) (p. 31). We find a cutoff of 0.044 and therefore drop zip codes with a propensity score lower than 0.044 or higher than 0.956 (=1 0.044). This leaves a sample of 69 zip codes. 
The second subsample used as a robustness check is trimmed based on the distance from the zip code centroid to the boundary of the Barnett Shale that divides the Dallas-Fort Worth region in half. Given the dependency of real estate markets on location-specific factors, zip codes closer to each other should be more comparable than zip codes further away, in which case trimming outlying zip codes should improve comparability. We trim the 25 percent of zip codes furthest from the shale boundary, either to the west or to the east. This gives a subsample of 59 zip codes, all of which are less than 45 kilometers from the shale boundary.

We present estimates based on the two trimmed subsamples for all estimates previously shown for the full sample.

\section{Estimates for Subsamples}

Both the propensity score-trimmed sample and the distance-trimmed sample show an evolution of housing values across shale and nonshale zip codes similar to that revealed by the full sample and shown in Figure 5 (see Appendix Figures A.1 and A.2). Shale and nonshale zip codes had similar housing values in the late 1990s and early 2000s, but then values diverged in the mid 2000s in favor of shale zip codes. Both subsamples show that the difference in values peaked around 2010-2011 and declined in subsequent years. According to both subsamples, in 2013 housing values in shale zip codes remained higher than in nonshale zip codes by roughly six percent.

Both subsamples also reveal similar changes in local public finances. The oil and gas tax base increased dramatically, peaking at in 2009 , with the difference between shale and nonshale zip codes having widened by about $\$ 85,000$ per student. Both subsamples also show no systematic differences in the tax base when excluding oil and gas and residential property. 
Regarding tax rates, in both cases, shale zip codes are shown to have systematically lower property tax rates in the later 2000 s.

The school revenue results differ slightly between the full sample and the two subsamples. The propensity-score-trimmed sample shows a larger and more persistent increase in school revenues per student in shale zip codes. From 2007 to 2010 school districts in shale zip codes had roughly $\$ 500$ more revenues per student than nonshale zip codes. The distancetrimmed sample shows a similar evolution over time but with smaller point estimates (around \$300 to \$400) and larger standard errors.

Moving to the capitalization estimates, we first verify the instrument strength for both subsamples (Appendix Table A1). The point estimates and $F$ statistics are very similar to those from the full sample. As with the full sample, when looking at the change in the tax base from 2000 to 2013 , the instrument is weak if the well density variables are included, otherwise the $F$ statistics range from 11.0 to 19.3 .

The capitalization estimates are robust to removing the shale and nonshale zip codes with the most unique initial socio-economic characteristics. The estimates based on the propensityscore-trimmed (Table 4) are similar to those from the full sample, both in magnitude and precision. The estimates for the effects on well density are also qualitatively similar, with mixed signs for recent wells and generally negative effects for the cumulative density of wells drilled.

The capitalization estimates based on the distance-trimmed sample are marginally smaller than those from the full or propensity-score-trimmed sample (Table 5). Using annual changes, the distance-trimmed sample indicates that a one-dollar per student increase in the oil and gas tax base is associated with a $\$ 0.10$ increase in the value of the typical home (columns 7 and 8 of Panel A in Table 5). The changes from 2000 to 2013 also give smaller capitalization estimates 
when compared with the full or propensity-score-trimmed samples. The marginally smaller point estimates combined with larger standard errors, likely stemming from the decline in sample size (only 59 zip codes) erodes the statistical significance of the estimates. Looking at the well density results, the coefficients remain qualitatively similar but are also statistically insignificant.

The slightly smaller capitalization estimates for the distance-trimmed sample might be because zip codes closer to the shale boundary tend to be more urban and have a larger initial tax base. The average initial tax base of the distance-trimmed sample is six percent larger than the full sample average tax base and nine percent larger than that of the propensity-score-trimmed sample. A given change in the oil and gas tax base would therefore have a smaller proportional effect on the tax base in the distance-trimmed sample than for the other samples.

\section{ALTERNATIVE INTERPRETATIONS AND CONFOUNDING FACTORS}

We interpret the statistical relationship between the oil and gas property tax base and housing values as reflecting the causal effect of the tax base. There are several potential confounding factors that might suggest a different interpretation.

\section{A Correlation with Labor and Housing Demand}

One interpretation of our findings is that the oil and gas tax base correlates with greater economic activity from drilling (e.g. Weber, 2012, 2014; Brown, 2014), which increased the demand for labor and housing. The large labor and housing market in the Dallas-Fort Worth region makes it unlikely that a relatively small labor shock would cause wage or housing appreciation and any localized effects should be captured by controlling for drilling activity. Moreover, if the correlation between the tax base and appreciation reflects labor shocks, we 
should see a smaller correlation when looking at the change from 2000 to 2013: by 2013 drilling had slowed to below 2001 levels, so drilling-related labor demand would have been negligible. Yet, appreciation from 2000 to 2013 shows an even larger effect of the oil and gas tax base.

We nonetheless probe this explanation further by estimating whether shale and nonshale counties had different employment trends in the shale boom and post-boom periods, where shale and nonshale counties are those containing the shale and nonshale zip codes of the full sample. We find that shale and nonshale counties experienced similar employment growth in the 2001 to 2008 period, when drilling boomed, and similar declines in employment over the 2009 to 2013 period when drilling slowed and the great recession hit (Appendix Table A2).

\section{Capitalization of Natural Gas Rights into Housing Values}

Another explanation is that housing values capitalize the rights to revenue from natural gas production, which are correlated with the oil and gas tax base. We do not control for local ownership of natural gas rights, or the value of natural gas production, which would affect the value of those rights. Evidence suggests that capitalization of natural gas rights is not the primary cause of greater appreciation in shale zip codes. Tarrant County has the most shale zip codes in our sample. Timmins and Vissing (2014) look at all the housing transactions in Tarrant County over the 2000 to 2013 period and show that having an active lease increases the value of the home by just four percent. Since only 28 percent of the housing transactions in their study involved an active lease, leasing would account for an average increase in housing values of just one percent. This is consistent with Weber and Hitaj (2015), which find evidence from farm real estate values in the Barnett Shale that surface owners generally do not own the rights to the gas beneath the surface. 
Furthermore, if natural gas rights reflect the expected revenues from royalties, the 50 percent decline in the price of natural gas at the end of 2008 (and persistently low prices afterward) would have substantially decreased their values, and with it, housing values in shale areas. We observe the opposite: relative to nonshale zip codes, housing in shale zip codes continued to gain value in 2008, 2009, and 2010.

\section{Confounding Construction and Housing Market Shocks}

Although our shale measures are uncorrelated with the level or growth in housing values prior to development of the Barnett Shale, the national housing boom and bust and subsequent recession, which the Dallas-Fort Worth region was not immune to, may have affected shale areas differently than nonshale areas. Using county-level data on building permits for 2000 through 2013, we find that shale counties did not experience greater growth in construction during the 2000 through 2008 period; nor did the bust disproportionately affect them (Appendix Table A3).

\section{CONCLUSION}

For Texas' Barnett Shale, we study how resource abundance and extraction affected the local property tax base, property tax rates, school funding, and ultimately, housing values. Because the value of natural gas wells is taxed as real property in Texas, a boom and bust in natural gas prices and in drilling in the Barnett Shale caused large changes in the oil and gas tax base-and therefore the total tax base-over our 2000 to 2013 study period.

Zip codes inside the shale appreciated more than those just outside the shale from the early 2000s to about 2011 and retained a nine percent advantage in housing values in 2013, five years after the rate of drilling began to slow. Taxation of natural gas wells as property provides 
the primary explanation for the greater appreciation. Appreciation closely followed changes in the oil and gas tax base, which caused a 23 percent increase in the total tax base from 2000 to 2009. The expansion allowed property tax rates to decline by nine percent and school revenues to increase modestly. Using spatial variation in geology and temporal variation in natural gas prices, we directly estimate how changes in the oil and gas tax base are capitalized into housing values and find that a $\$ 1$ per student increase in the oil and gas property tax base led to a $\$ 0.15$ increase in the value of the typical home.

Without taxation of natural gas wells as property, drilling in the Barnett Shale would have had a minimal effect on the property tax base and a potentially negative effect on housing values. Some results suggest that the cumulative density of wells drilled in a zip code lowers housing values, which is consistent with opposition to shale development in parts of the U.S. and abroad where there are fewer channels for extractive activities to fund local public institutions. It is also consistent with Muehlenbachs et al. (2012, 2015) and Gopalakrishnan and Klaiber (2013) who both found negative effects for some types of properties in Pennsylvania, a state that does not tax oil and gas wells as property.

Our findings highlight how the consequences of natural resource development can hinge on having policies that turn natural resource windfalls into benefits enjoyed more broadly and for a longer time. Regardless of whether someone in New York owns the natural gas in the ground in Tarrant County, Texas, state policy ensures that she will pay property taxes on the value of any associated wells. Absentee ownership of resources, therefore, does not preclude local financial benefits of resource abundance. Property taxes in particular fund schools and public services where extraction occurs. This is in contrast to severance taxes which generate revenue 
for state governments that spend revenues broadly, potentially leaving schools and local governments in producing areas with modest, if any, financial gains.

The long-term effects of resource abundance on a locality likely depend on channels for revenues from development to fund enduring public amenities. Property tax cuts that can be sustained for only a few years likely have large but short-lived effects on welfare and housing values. With such a policy, part of the associated private financial gains will be spent on consumption or invested outside the locality and therefore generate modest, if any, long-term local benefits. In contrast, property tax windfalls spent on new parks and school buildings or improved roads and sidewalks, which can last for decades and are inherently tied to the locality, could have more enduring effects, especially if they encourage private investment and help maintain the value of the total tax base. Our results show that school districts spent at least some of their windfalls on property tax relief. We did not explore if city, municipal, or county governments responded similarly or if they invested or saved their revenue windfalls.

Our observations regarding resource-induced tax base shocks can be generalized in part. Resources like oil or gas are exhaustible and will often provide a one-time tax base windfall, which is distinct from general oscillations in real estate values or from the building of a large commercial property that provides a more enduring tax base expansion. Nevertheless, the same causal relationships between the tax base, local amenities, tax rates, and housing values likely hold in a variety of contexts. 


\section{FIGURES}

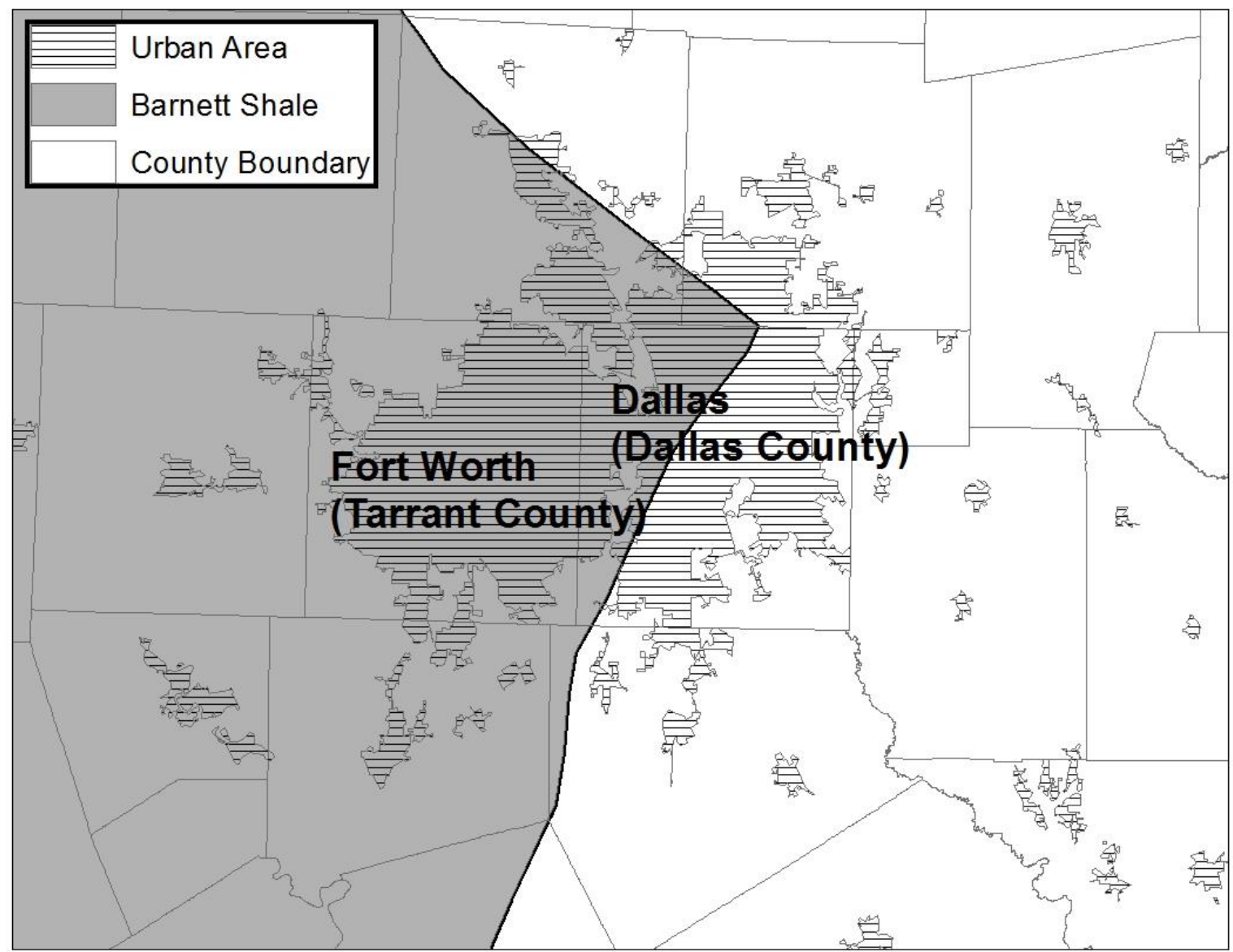

Figure 1. The Barnett Shale Splits the Dallas-Fort Worth Region

Source: Elaboration by the authors using spatial data from the U.S. Energy Information Administration (shale area) and the U.S. Census Bureau (urban areas). 


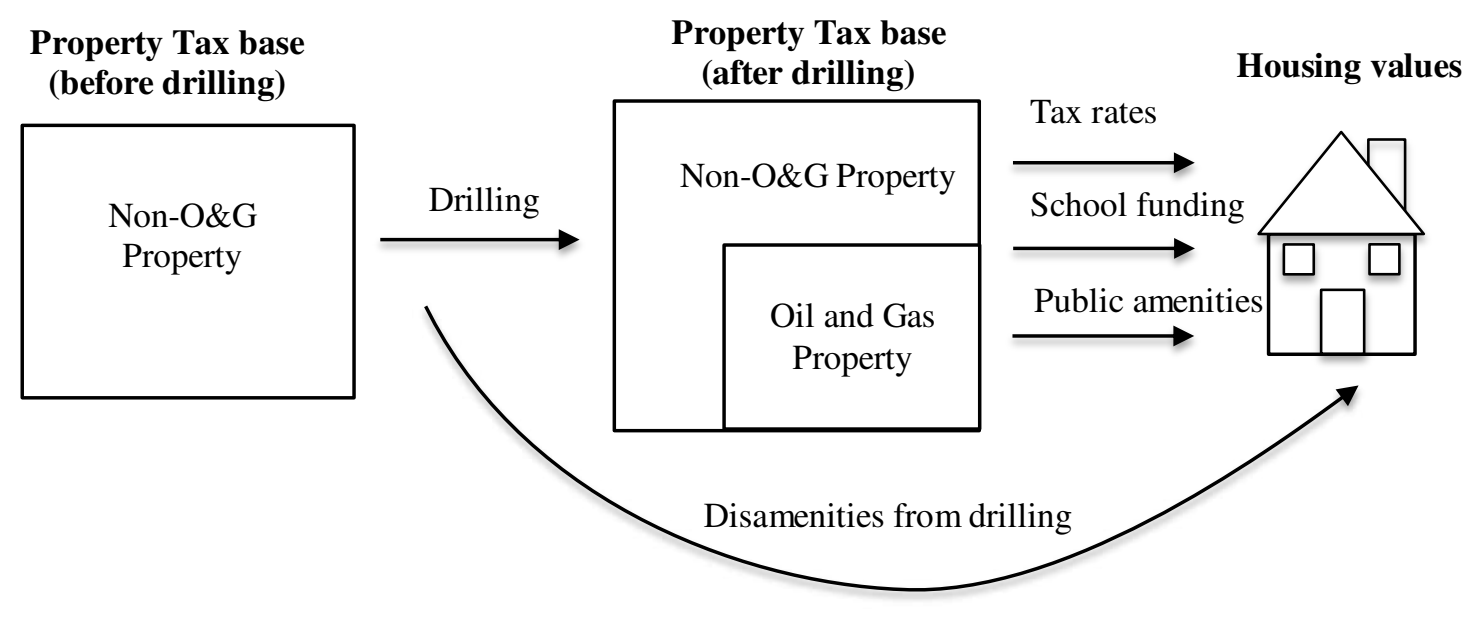

Figure 2. Linking Shale Development and Housing Values Note: Elaboration by the authors. 


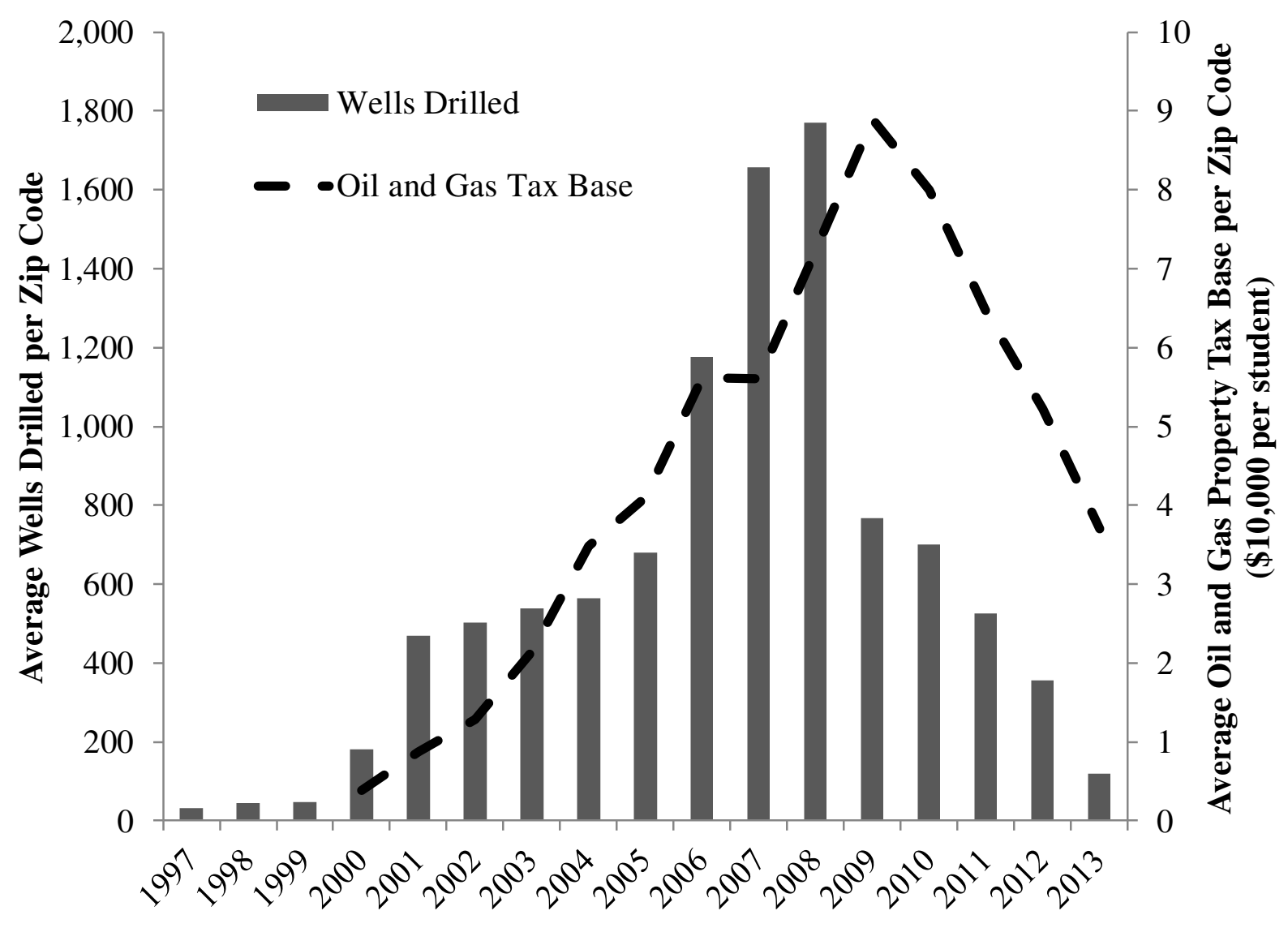

Figure 3. Wells Drilled and the Oil and Gas Property Tax Base in Shale Zip Codes, 1997-2013

Source: Elaboration by the authors using data from DrillingInfo (wells) and the Texas Education Agency (oil and gas property tax base). Shale and nonshale zip codes are as defined in the Data and Sample section. 


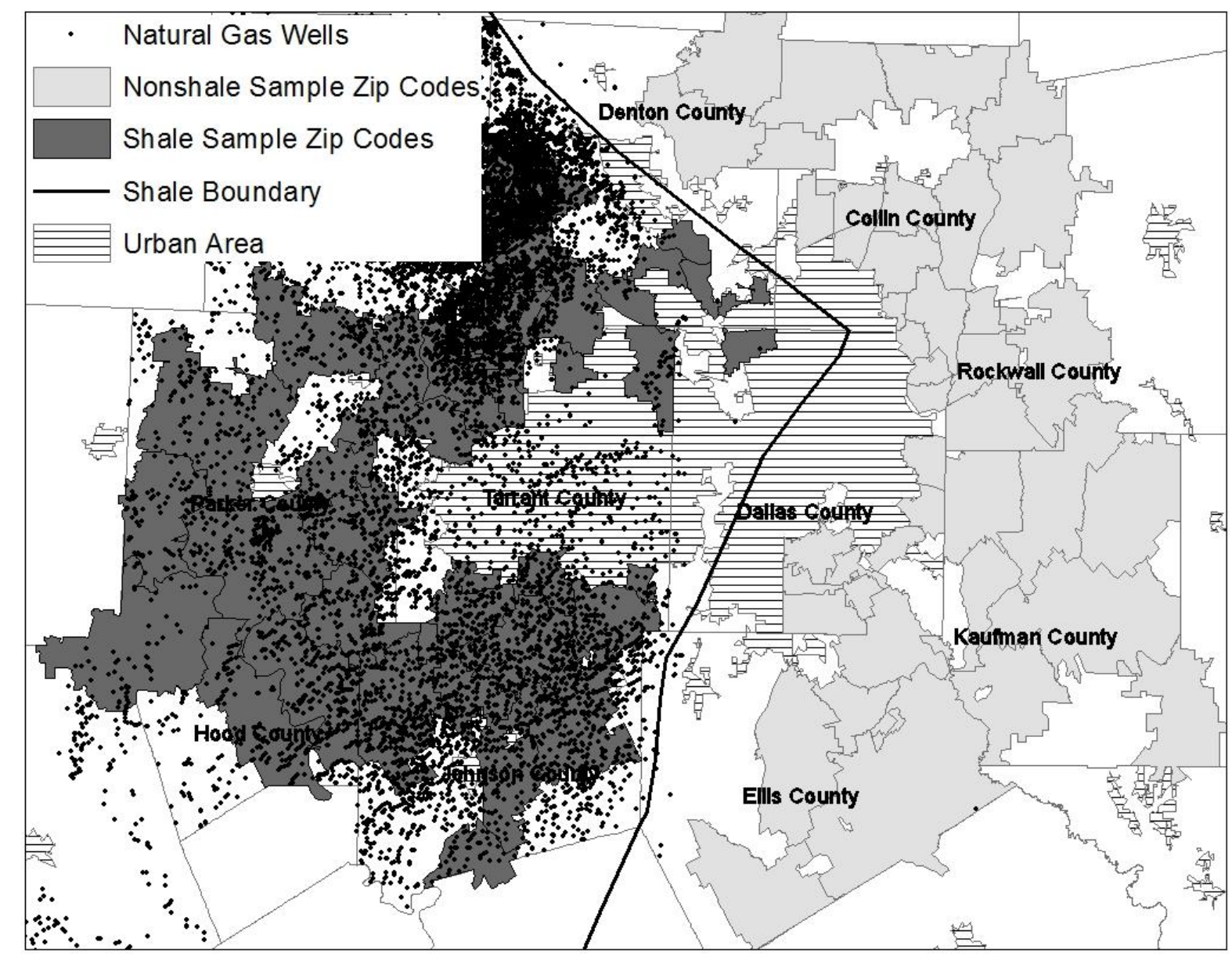

Figure 4. Shale and Nonshale Zip Codes and Wells Drilled

Note: Elaboration by the authors using data from DrillingInfo (wells), the U.S. Energy Information Administration (shale boundary), and the Census Bureau (urban areas). County names are in bold. Sample zip codes are those for which Zillow housing value data are available for the study period and that are less than 75 percent urban. Shale zip codes are those sample zip codes entirely within the shale; nonshale zip codes are those entirely outside of the shale. 


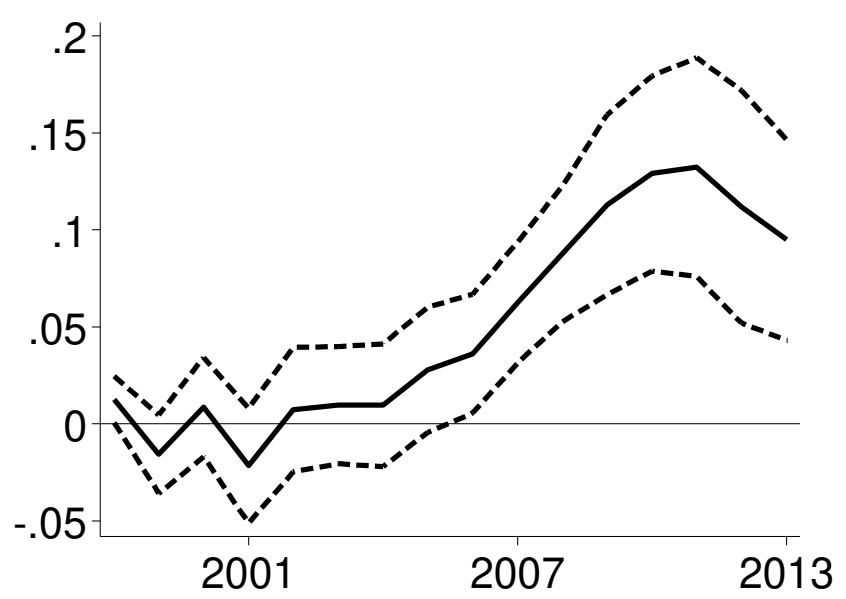

(a) Log ZHVI

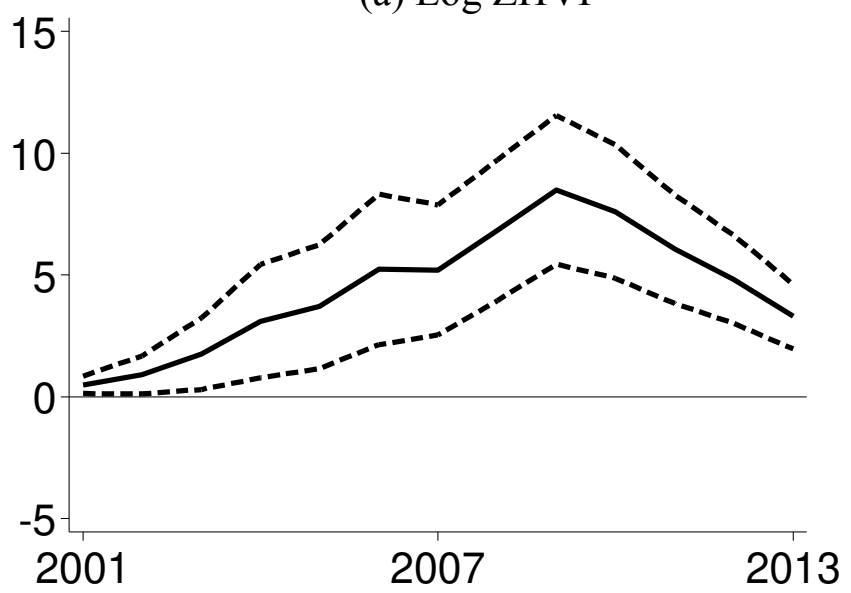

(c) Oil and Gas Tax Base $(\$ 10,000$ /student $)$

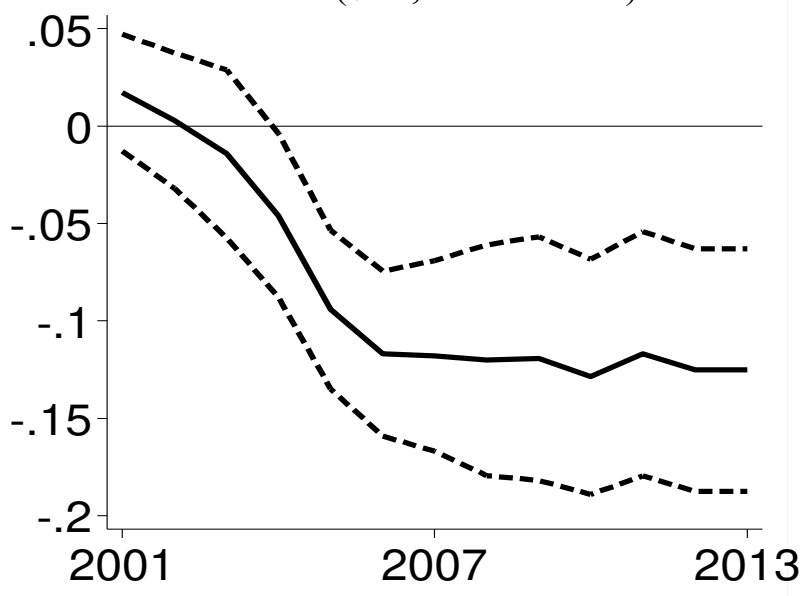

(e) Property Tax Rate (\%)

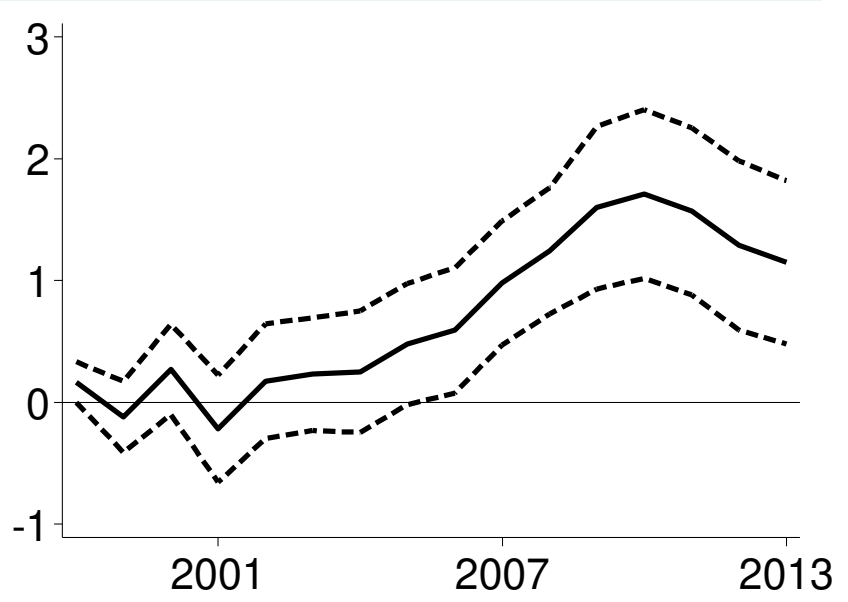

(b) ZHVI $(\$ 10,000)$

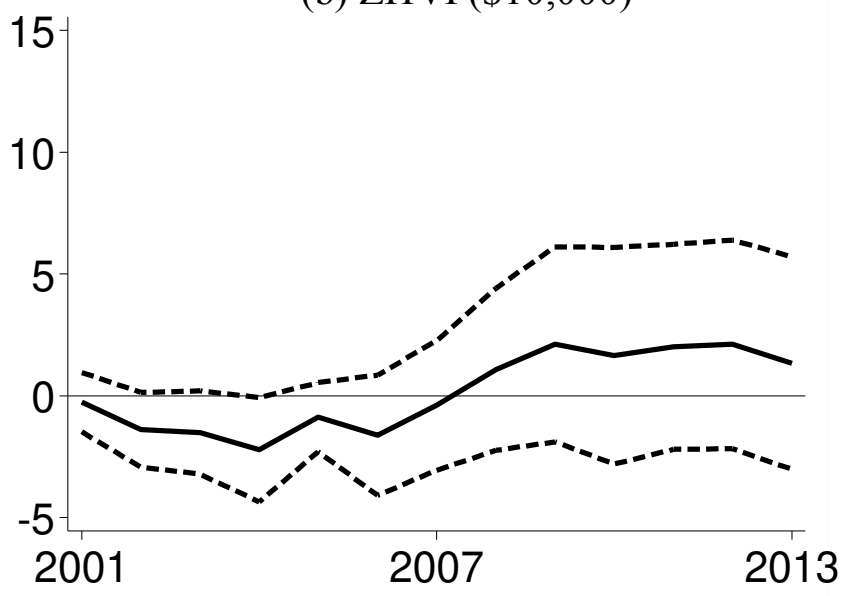

(d) Non-O\&G, Non-Residential Tax Base $(\$ 10,000$ /student $)$

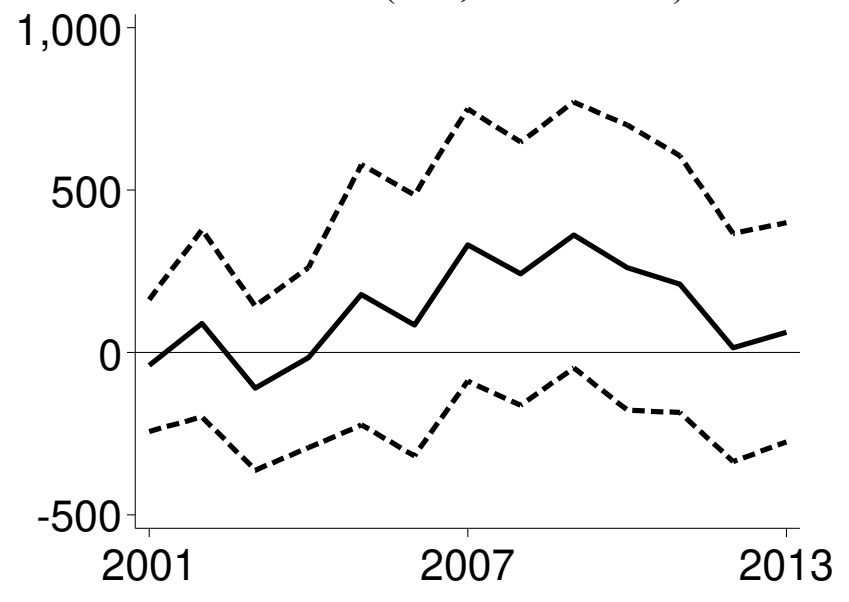

(f) School Revenues (\$/student)

Figure 5. The Change in Conditional Mean Differences Across Shale and Nonshale Zip Codes

Note: Data are from Zillow (ZHVI), the Texas Education Agency (the tax base and school spending), and the Texas Bond Review Board (property tax rates). The black line represents the coefficients on the interactions between the shale binary variable and the year binary variables estimated using equation (1). The dashed gray lines represent the $95 \%$ confidence intervals. 


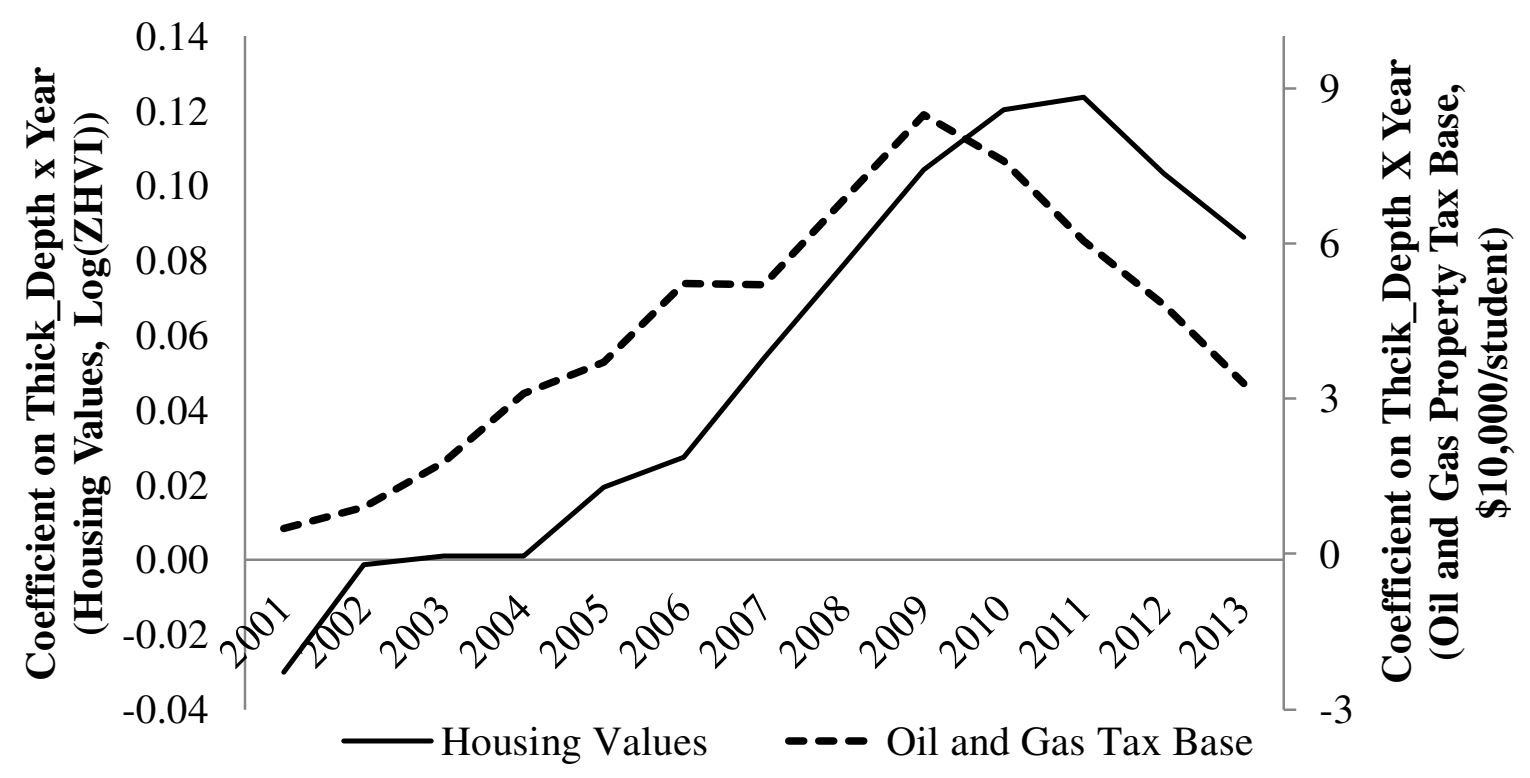

Figure 6. The Oil and Gas Tax Base and Housing Values

Note: The solid line represents the coefficients on the Shale and year interactions estimated using equation (1). The dashed line represents the coefficients on the Shale and year interactions estimated using the same equation but with the oil and gas tax base as the dependent variable. The excluded year for the housing value regression is 1997; for the oil and gas tax base regression it is 2000. 


\section{TABLES}

Table 1. Descriptive statistics for sample zip codes

\begin{tabular}{|c|c|c|c|c|c|c|}
\hline & \multicolumn{6}{|c|}{ Public Finance Variables, 2000 Levels } \\
\hline & \multicolumn{2}{|c|}{ All $(\mathrm{N}=79)$} & \multirow{2}{*}{$\begin{array}{c}\begin{array}{c}\text { Shale } \\
(\mathrm{N}=37)\end{array} \\
\text { Mean }\end{array}$} & \multirow{2}{*}{$\begin{array}{c}\text { Nonshale } \\
(\mathrm{N}=42)\end{array}$} & \multirow{2}{*}{$\begin{array}{l}\text { Difference in } \\
\text { Means }\end{array}$} & \multirow{2}{*}{$\begin{array}{l}\text { Statistically Different } \\
\text { Means? (P-value) }\end{array}$} \\
\hline & Mean & S.D. & & & & \\
\hline $\begin{array}{l}\text { Total property tax base } \\
\text { (\$10,000/student) }\end{array}$ & 35.0 & 18.6 & 38.2 & 32.2 & 6.0 & 0.16 \\
\hline Oil and gas & 0.2 & 0.5 & 0.4 & 0.0 & 0.4 & 0.00 \\
\hline Residential & 18.2 & 9.3 & 18.3 & 18.2 & 0.1 & 0.95 \\
\hline Non-O\&G, non-residential & 16.6 & 12.3 & 19.5 & 14.0 & 5.4 & 0.05 \\
\hline School property tax rate $(\%)$ & 1.54 & 0.11 & 1.58 & 1.50 & 0.1 & 0.00 \\
\hline School revenues (\$/student) & 9,356 & 992 & 9,444 & 9,278 & 166 & 0.46 \\
\hline \multirow[t]{2}{*}{ Total students $(1,000 \mathrm{~s})$} & 1.87 & 3.40 & 1.16 & 2.49 & -1.3 & 0.08 \\
\hline & \multicolumn{6}{|c|}{ Drilling Activity (Wells per Square Kilometer) } \\
\hline Wells drilled in 2000 & 0.01 & 0.07 & 0.03 & 0.00 & 0.03 & 0.04 \\
\hline \multirow[t]{2}{*}{ Cumulative wells drilled, 2000-2013 } & 0.91 & 1.52 & 1.94 & 0.00 & 1.94 & 0.00 \\
\hline & \multicolumn{6}{|c|}{ Pre-Boom Levels and Trends in Housing Values, 1997-2000 } \\
\hline Annual $\ln (\mathrm{ZHVI})$ & 11.86 & 0.34 & 11.88 & 11.84 & 0.04 & 0.26 \\
\hline Annual ZHVI $(\$ 10,000)$ & 15.01 & 5.51 & 15.18 & 14.87 & 0.31 & 0.62 \\
\hline Annual $\Delta \ln (\mathrm{ZHVI})$ & 0.033 & 0.039 & 0.034 & 0.031 & 0.003 & 0.57 \\
\hline Annual $\Delta$ ZHVI $(\$ 10,000)$ & 0.45 & 0.56 & 0.50 & 0.41 & 0.09 & 0.22 \\
\hline
\end{tabular}


Table 2. First-Stage results for changes in the oil and gas property tax base ( $\$ 10,000 /$ student $)$

\section{Panel A: Annual Changes}

\begin{tabular}{lcc} 
Variables & $\Delta$ O\&G Tax Base \\
\hline (Thick_Depth) x $\Delta \ln$ (Price), t-1 & $0.324 * * *$ & $0.281^{* * *}$ \\
& $(0.076)$ & $(0.064)$ \\
Wells drilled/sq. km, t, t-1 & & $1.994^{* * *}$ \\
& & $(0.394)$ \\
Cumulative wells drilled/sq. km, t-2 & $-0.276^{* * *}$ \\
& & $(0.054)$ \\
Intercept & -0.051 & $-0.169^{* *}$ \\
& $(0.037)$ & $(0.072)$ \\
\hline F statistic on (Thick_Depth) $\mathrm{x} \Delta \ln$ (Price), t-1 & 18.0 & 19.2 \\
Zip codes & 79 & 79 \\
Observations & 948 & 948 \\
Adjusted R squared & 0.14 & 0.27 \\
\hline
\end{tabular}

Panel B: Change 2000-2013

\begin{tabular}{lcc} 
Variables & $\Delta$ O\&G Tax Base \\
\hline (Thick_Depth) x $\Delta \ln$ (Price), 2000-2012 & $-6.569^{* * *}$ & $-2.845^{* *}$ \\
& $(1.475)$ & $(1.219)$ \\
Wells drilled/sq. km, 2012, 2013 & & -0.097 \\
& & $(4.398)$ \\
Cumulative wells drilled/sq. km, 2011 & $1.306^{* *}$ \\
& & $(0.540)$ \\
Intercept & -0.004 & 0.024 \\
& $(0.167)$ & $(0.134)$ \\
\hline F statistic on (Thick_Depth) x $\Delta \ln$ (Price), t-1 & 19.8 & 5.4 \\
Zip codes & 79 & 79 \\
Observations & 79 & 79 \\
Adjusted R squared & 0.30 & 0.41 \\
\hline
\end{tabular}

Note: $* * *, * * *$ indicate statistical significance at the 1, 5, and 10 percent levels. The results in Panel A exploit annual variation over the 2000 to 2013 period. For these results, robust standard errors clustered by zip code are in parenthesis. Year dummy variables are included in the annual-based regression but excluded from the table. The results in Panel B are based on differencing 2000 values from 2013 values, thereby converting the panel into a cross section of zip codes. For these results, unclustered robust standard errors are in parenthesis. 
Table 3. Capitalization of the oil and gas property tax base into housing values, full sample

\begin{tabular}{|c|c|c|c|c|c|c|c|c|}
\hline & \multicolumn{8}{|c|}{ Panel A: Annual Changes } \\
\hline & OLS & OLS & IV & IV & OLS & OLS & IV & IV \\
\hline Wells drilled/sq. km, t, t-1 & & $\begin{array}{c}0.002 \\
(0.002)\end{array}$ & & $\begin{array}{l}-0.002 \\
(0.004)\end{array}$ & & $\begin{array}{c}0.027 \\
(0.024)\end{array}$ & & $\begin{array}{l}-0.074 \\
(0.051)\end{array}$ \\
\hline Cumulative wells drilled/sq. km, t-2 & & $\begin{array}{l}-0.001 * \\
(0.001)\end{array}$ & & $\begin{array}{c}0.000 \\
(0.001)\end{array}$ & & $\begin{array}{c}-0.032 * * * \\
(0.011)\end{array}$ & & $\begin{array}{c}0.008 \\
(0.020)\end{array}$ \\
\hline Observations & 948 & 948 & 948 & 948 & 948 & 948 & 948 & 948 \\
\hline Adjusted R Squared & 0.52 & 0.52 & 0.51 & 0.51 & 0.57 & 0.57 & 0.51 & 0.51 \\
\hline
\end{tabular}

Panel B: Change 2000-2013

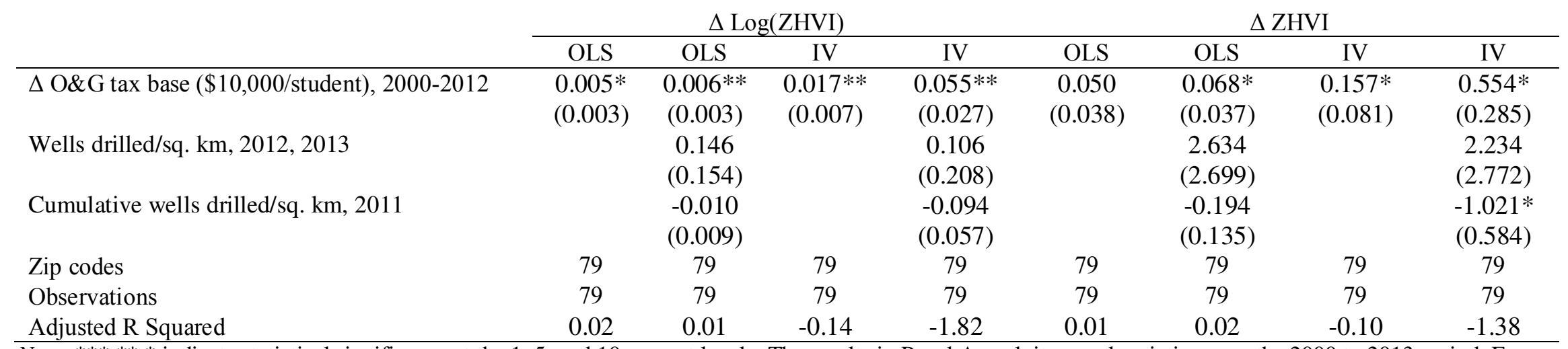

Note: $* * *, * * *$ indicate statistical significance at the 1, 5, and 10 percent levels. The results in Panel A exploit annual variation over the 2000 to 2013 period. For these results, robust standard errors clustered by zip code are in parenthesis. Year dummy variables are included in the annual-based regression but excluded from the table. The results in Panel B are based on differencing 2000 values from 2013 values, thereby converting the panel into a cross section of zip codes. For these results, unclustered robust standard errors are in parenthesis. 
Table 4. Capitalization of the oil and gas property tax base into housing values, propensity-score-trimmed sample

Panel A: Annual Changes

\begin{tabular}{|c|c|c|c|c|c|c|c|c|}
\hline & \multicolumn{4}{|c|}{$\Delta \log (\mathrm{ZHVI})$} & \multicolumn{4}{|c|}{$\Delta$ ZHVI } \\
\hline & OLS & OLS & IV & IV & OLS & OLS & IV & IV \\
\hline \multirow[t]{2}{*}{$\Delta \mathrm{O} \& \mathrm{G}$ tax base $(\$ 10,000 /$ student $), \mathrm{t}-1$} & $0.002^{* *}$ & $0.002^{* *}$ & $0.008^{*}$ & $0.008 *$ & $0.028 * * *$ & $0.025^{* *}$ & $0.139 * *$ & $0.145^{* *}$ \\
\hline & $(0.001)$ & $(0.001)$ & $(0.004)$ & $(0.004)$ & $(0.010)$ & $(0.010)$ & $(0.061)$ & $(0.067)$ \\
\hline \multirow[t]{2}{*}{ Wells drilled/sq. km, t, t-1 } & & 0.000 & & -0.005 & & 0.019 & & -0.076 \\
\hline & & $(0.002)$ & & $(0.004)$ & & $(0.025)$ & & $(0.052)$ \\
\hline \multirow[t]{2}{*}{ Cumulative wells drilled/sq. km, t-2 } & & $-0.002 *$ & & 0.000 & & $-0.031 * * *$ & & 0.006 \\
\hline & & $(0.001)$ & & $(0.001)$ & & $(0.011)$ & & $(0.020)$ \\
\hline Zip codes & 79 & 79 & 79 & 79 & 79 & 79 & 79 & 79 \\
\hline Observations & 828 & 828 & 828 & 828 & 828 & 828 & 828 & 828 \\
\hline Adjusted R Squared & 0.54 & 0.54 & 0.50 & 0.50 & 0.57 & 0.57 & 0.50 & 0.50 \\
\hline
\end{tabular}

Panel B: Change 2000-2013

\begin{tabular}{|c|c|c|c|c|c|c|c|c|}
\hline & \multicolumn{4}{|c|}{$\Delta \log (\mathrm{ZHVI})$} & \multicolumn{4}{|c|}{$\Delta$ ZHVI } \\
\hline & OLS & OLS & IV & IV & OLS & OLS & IV & IV \\
\hline \multirow[t]{2}{*}{$\Delta \mathrm{O} \& \mathrm{G}$ tax base $(\$ 10,000 /$ student $), 2000-2012$} & 0.003 & $0.005 *$ & $0.011 *$ & $0.042 *$ & 0.043 & $0.065^{*}$ & $0.142 *$ & $0.516^{*}$ \\
\hline & $(0.002)$ & $(0.003)$ & $(0.006)$ & $(0.022)$ & $(0.037)$ & $(0.036)$ & $(0.080)$ & $(0.274)$ \\
\hline \multirow[t]{2}{*}{ Wells drilled/sq. km, 2013, 2012} & & 0.126 & & 0.100 & & 2.551 & & 2.232 \\
\hline & & $(0.164)$ & & $(0.178)$ & & $(2.750)$ & & $(2.720)$ \\
\hline \multirow[t]{2}{*}{ Cumulative wells drilled/sq. km, 2011} & & -0.014 & & -0.076 & & -0.210 & & $-0.965 *$ \\
\hline & & $(0.010)$ & & $(0.047)$ & & $(0.136)$ & & $(0.554)$ \\
\hline
\end{tabular}

Zip codes

$\begin{array}{cccccccc}69 & 69 & 69 & 69 & 69 & 69 & 69 & 69 \\ 69 & 69 & 69 & 69 & 69 & 69 & 69 & 69 \\ 0.01 & 0.00 & -0.12 & -1.73 & 0.00 & 0.01 & -0.10 & -1.40\end{array}$

Adjusted R Squared

$\begin{array}{lll}0.01 & 0.00 & -0.12\end{array}$

$-1.73$

0.00

$0.01 \quad-0.10 \quad-1.40$

Note: ***,**** indicate statistical significance at the 1, 5, and 10 percent levels. The results in Panel A exploit annual variation over the 2000 to 2013 period. For these results, robust standard errors clustered by zip code are in parenthesis. Year dummy variables are included in the annual-based regression but excluded from the table. The results in Panel B are based on differencing 2013 values from 2000 values, thereby converting the panel into a cross section of zip codes. For these results, unclustered robust standard errors are in parenthesis. The propensity-score-trimmed sample is based on trimming the full sample using optimal cutoffs based on the estimated propensity to be a shale zip code based on socioeconomic characteristics as described in the text. 
Table 5. Capitalization of the oil and gas property tax base into housing values, distance-trimmed sample

Panel A: Annual Changes

\begin{tabular}{|c|c|c|c|c|c|c|c|c|}
\hline & \multicolumn{4}{|c|}{$\Delta \log (\mathrm{ZHVI})$} & \multicolumn{4}{|c|}{$\Delta$ ZHVI } \\
\hline & OLS & OLS & IV & IV & OLS & OLS & IV & IV \\
\hline \multirow[t]{2}{*}{$\Delta \mathrm{O} \& \mathrm{G}$ tax base $(\$ 10,000 /$ student $), \mathrm{t}-1$} & $0.001 *$ & 0.001 & 0.003 & 0.002 & $0.020 * *$ & $0.015^{*}$ & $0.097 *$ & $0.099 *$ \\
\hline & $(0.001)$ & $(0.001)$ & $(0.003)$ & $(0.003)$ & $(0.009)$ & $(0.009)$ & $(0.053)$ & $(0.056)$ \\
\hline \multirow[t]{2}{*}{ Wells drilled/sq. km, t, t-1 } & & 0.001 & & 0.000 & & 0.022 & & -0.048 \\
\hline & & $(0.002)$ & & $(0.003)$ & & $(0.021)$ & & $(0.044)$ \\
\hline \multirow[t]{2}{*}{ Cumulative wells drilled/sq. km, t-2 } & & -0.001 & & -0.001 & & $0.026 * *$ & & 0.003 \\
\hline & & $(0.001)$ & & $(0.001)$ & & $(0.012)$ & & $(0.018)$ \\
\hline Zip codes & 59 & 59 & 59 & 59 & 59 & 59 & 59 & 59 \\
\hline Observations & 708 & 708 & 708 & 708 & 708 & 708 & 708 & 708 \\
\hline Adjusted R Squared & 0.63 & 0.63 & 0.63 & 0.63 & 0.69 & 0.69 & 0.66 & 0.66 \\
\hline
\end{tabular}

Panel B: Change 2000-2013

\begin{tabular}{|c|c|c|c|c|c|c|c|c|}
\hline & \multicolumn{4}{|c|}{$\Delta \log (\mathrm{ZHVI})$} & \multicolumn{4}{|c|}{$\Delta \mathrm{ZHVI}$} \\
\hline & OLS & OLS & IV & IV & OLS & OLS & IV & IV \\
\hline \multirow[t]{2}{*}{$\Delta \mathrm{O} \& \mathrm{G}$ tax base ( $\$ 10,000 /$ student), $2000-2012$} & 0.002 & 0.001 & 0.012 & 0.062 & -0.008 & 0.006 & 0.081 & 0.589 \\
\hline & $(0.003)$ & $(0.004)$ & $(0.008)$ & $(0.048)$ & $(0.039)$ & $(0.056)$ & $(0.091)$ & $(0.483)$ \\
\hline \multirow[t]{2}{*}{ Wells drilled/sq. km, 2013, 2012} & & -0.177 & & -0.087 & & -2.638 & & -1.778 \\
\hline & & $(0.106)$ & & $(0.281)$ & & $(1.607)$ & & (2.999) \\
\hline \multirow[t]{2}{*}{ Cumulative wells drilled/sq. km, 2011} & & 0.006 & & -0.095 & & 0.040 & & -0.932 \\
\hline & & $(0.012)$ & & $(0.090)$ & & $(0.164)$ & & $(0.886)$ \\
\hline Zip codes & 59 & 59 & 59 & 59 & 59 & 59 & 59 & 59 \\
\hline Observations & 59 & 59 & 59 & 59 & 59 & 59 & 59 & 59 \\
\hline Adjusted R Squared & -0.02 & -0.04 & -0.11 & -1.47 & -0.02 & -0.03 & -0.08 & -1.24 \\
\hline
\end{tabular}

Note: $* * *, * * *$ indicate statistical significance at the 1,5 , and 10 percent levels. The results in Panel A exploit annual variation over the 2000 to 2013 period. For these results, robust standard errors clustered by zip code are in parenthesis. Year dummy variables are included in the annual-based regression but excluded from the table. The results in Panel B are based on differencing 2013 values from 2000 values, thereby converting the panel into a cross section of zip codes. For these results, unclustered robust standard errors are in parenthesis. The distance-trimmed sample is based on removing the 25 percent of zip codes in the full sample that were furthest from the eastern boundary of the Barnett Shale. 


\section{REFERENCES}

Abramzon, S., Samaras, C., Curtright, A., Litovitz, A., \& Burger, N. (2014). Estimating the consumptive use costs of shale natural gas extraction on Pennsylvania roadways. Journal of Infrastructure Systems, 20.

Aguilera, R.F., \& Radetzki, M. (2013). Shale gas and oil: Fundamentally changing global energy markets. Oil and Gas Journal, 111, 54-61.

Angrist, J. D., \& Kugler, A.D. (2008). Rural windfall or a new resource curse? Coca, income, and civil conflict in Colombia. The Review of Economics and Statistics, 90, 191-215.

Angrist, J.D., \& Pischke, J.S. (2009). Mostly Harmless Econometrics. Princeton, NJ: Princeton University Press.

Barrow, L., \& Rouse, C. E. (2004). Using market valuation to assess public school spending. Journal of Public Economics, 88, 1747-1769.

Bergstrom, T.C. \& Goodman, R.P. (1973). Private demands for public goods. The American Economic Review, 63, 280-296.

Bifulco, R. (2012) Can nonexperimental estimates replicate estimates based on random assignment in evaluations of school choice? A within-study comparison. Journal of Policy Analysis and Management, 31, 729-751.

Binet, M.-E. (2013). The linear expenditure system and the demand for municipal public services: The median voter specification revisited. Urban Studies, 50, 1689-1703.

Black, D., McKinnish, T., \& Sanders, S.G. (2005a). The economic impact of the coal boom and bust. The Economic Journal, 115, 449-476.

Black, D. A., McKinnish, T., \& Sanders, S.G. (2005b). Tight labor markets and the demand for education: Evidence from the coal boom and bust. Industrial \& Labor Relations Review, 59, 3-16.

Boslett, A., Guilfoos, T., \& Lang, C. 2015. Valuation of expectations: a hedonic study of shale gas development and New York's Moratorium. Journal of Environmental Economics and Management, 77, 14-30.

Bradbury, K. L., Mayer, C. J., \& Case, K. E. (2001). Property tax limits, local fiscal behavior, and property values: Evidence from Massachusetts under Proposition 212. Journal of Public Economics, 80, 287-311. 
Brown, J.P. (2014). Production of natural gas from shale in local economies: A resource blessing or curse? Economic Review, Federal Reserve Bank of Kansas City, 119-147.

Brown, J.P., Fitzgerald, T., \& Weber, J.G. (2015). Capturing rents from natural resource abundance: private royalties from us onshore oil and gas production. Federal Reserve Bank of Kansas City, Working Paper 15-04. Retrieved July 5, 2015, from https://www.kansascityfed.org/ /media/files/publicat/reswkpap/pdf/2015/rwp15-04.pdf.

Browning, J., Tinker, S.W., Ikonnikova, S., Gülen, G., Potter, E., Fu, Q., Horvath, S., Patzek, T., Male, F., Fisher, W., Roberts, F, \& Medlock III, K. (2013). Barnett Shale model-1: Study develops decline analysis, geologic parameters for reserves, production forecast. Oil and Gas Journal, 111.

Buettner, T. (2003). Tax base effects and fiscal externalities of local capital taxation: evidence from a panel of German jurisdictions. Journal of Urban Economics, 54, 110-128.

Caselli, F., \& Michaels, G. (2013). Do oil windfalls improve living standards? Evidence from Brazil. American Economic Journal: Applied Economics, 5, 208-38.

Courant, P.N., \& Loeb, S. (1997). Centralization of school finance in Michigan. Journal of Policy Analysis and Management, 16, 114-136.

Crump, R.K., Hotz, J.V., Imbens, G.W., \& Mitnik, O.A. (2009). Dealing with limited overlap in the estimation of average treatment effects. Biometrika, 96, 187-199.

Di, W., Ma, J. \& Murdoch, J.C. (2010). An analysis of the neighborhood impacts of a mortgage assistance program: A spatial hedonic model. Journal of Policy Analysis and Management, 29, 682-697.

Dorsey, R.E., Hu, H., Mayer, W.J., \& Wang, H. (2010). Hedonic versus repeat-sales housing price indexes for measuring the recent boom-bust cycle. Journal of Housing Economics, $19,75-93$.

Edel, M., \& Sclar, E. (1974). Taxes, spending, and property values: Supply adjustment in a Tiebout-Oates model. Journal of Political Economy, 82, 941-954.

Ellen, I.G. \& Voicu, I. (2010). Nonprofit housing and neighborhood spillovers. Journal of Policy Analysis and Management, 25, 31-52.

Environmental Protection Agency. (2011). Draft plan to study the potential impacts of hydraulic fracturing on drinking water resources. EPA, Washington, DC. Retrieved November 22, 2014, from www.yosemite.epa.gov. 
Foster, J. M., \& Fowles, J. (2014). Easy money: Tax exporting and state support for higher education. Journal of Policy Analysis and Management, 1-26. Retrieved June 16, 2015 from http://onlinelibrary.wiley.com/doi/10.1002/pam.21813/epdf.

Gopalakrishnan, S., \& Klaiber, H. A. (2013). Is the shale energy boom a bust for nearby residents? Evidence from housing values in Pennsylvania. American Journal of Agricultural Economics, 96, 43-66.

Guerrieri, V., Hartley, D., \& Hurst, E. (2010). Endogenous gentrification and housing price dynamics. NBER Working Paper No. 16237. National Bureau of Economic Research. Retrieved June 12, 2014, from http://www.nber.org/papers/w16237.

Hanushek, E. A. (1981). Throwing money at schools. Journal of Policy Analysis and Management, 1, 19-41.

Huang, H. \& Tang, Y. (2012). Residential land use regulation and the US housing price cycle between 2000 and 2009. Journal of Urban Economics, 71, 93-99.

Hill, E. L. (2012). Unconventional natural gas development and infant health: Evidence from Pennsylvania. Charles H. Dyson School of Applied Economics and Management Working Paper 2012-12. Retrieved March 14, 2015 from https://www.researchgate.net/publication/241750826_Unconventional_Natural_Gas_Dev elopment_and_Infant_Health_Evidence_from_Pennsylvania.

Ho, D., Imai, K., King, G., \& Stuart, E. (2007). Matching as nonparametric preprocessing for reducing model dependence in parametric causal inference. Political Analysis, 15, 199_ 236.

Humphies, S. (2008). Zillow Home Value Index compared to OFHEO and Case-Shiller Indexes. Retrieved February 27, 2014 from http://www.zillowblog.com/2008-03-18/zillow-homevalue-index-compared-to-ofheo-and-case-shiller-indexes/.

Imbens, G. (2014a). Instrumental variables: An econometrician's perspective. National Bureau of Economic Research, Working Paper 19983. Retrieved May 17, 2014, from http://www.nber.org/papers/w19983.

Imbens, G. (2014b). Matching methods in practice: Three examples. National Bureau of Economic Research, Working Paper 19959. Retrieved May 17, 2014, from http://www.nber.org/papers/w19959. 
Jacobsen, G. D., \& Parker, D. P. (2014). The economic aftermath of resource booms: evidence from boomtowns in the American West. In press, The Economic Journal.

Kaiser, M. J. \& Yu, Y. (2015). Drilling and completion cost in the Louisiana Haynesville shale, 2007-2012. Natural Resources Research, 24, 5-31.

Kargbo, D.M., Wilhelm, R.G., \& Campbell, D.J. (2010). Natural gas plays in the Marcellus Shale: Challenges and potential opportunities. Environmental Science and Technology, 44, 5679-5684.

Lang, K., \& Jian, T. (2004). Property taxes and property values: Evidence from Proposition 212. Journal of Urban Economics, 55, 439-457.

Litovitz, A., Curtright, A., Abramzon, S., Burger, N., \& C. Samaras. (2013). Estimation of regional air-quality damages from Marcellus Shale natural gas extraction in Pennsylvania. Environmental Research Letters, 8, 1-8.

Marchand, J. (2012). Local labor market impacts of energy boom-bust-boom in Western Canada. Journal of Urban Economics, 71, 165-174.

Marchand, J., \& Weber, J.G. (2015). The labor market and school finance effects of the Texas shale boom on teacher quality and student achievement. University of Alberta Working Paper No. 2015-15. Retrieved September 12, 2015, from http://www.ualberta.ca/ econwps/2015/wp2015-15.pdf.

Michaels, G. (2011). The long-term consequences of resource- based specialization. The Economic Journal, 121, 31-57.

Muehlenbachs, L., Spiller, E., \& Timmins, C. (2012). Shale gas development and property values: Differences across drinking water sources. National Bureau of Economic Research, Working Paper Number 18390. Retrieved April 2, 2014, from http://www.nber.org/papers/w18390.

Muehlenbachs, Spiller, E., \& Timmins, C. (2015). The housing market impacts of shale gas development. American Economic Review, 105, 3633-3659.

Oates, W. E. (1969). The effects of property taxes and local public spending on property values: An empirical study of tax capitalization and the Tiebout hypothesis. Journal of Political Economy, 77, 957-971.

Popkin, J. H., Duke, J. M., Borchers, A. M., \& Ilvento, T. (2013). Social costs from proximity to hydraulic fracturing in New York State. Energy Policy, 62, 62-69. 
Poterba, J. M. (1997). Political economy of public education. Journal of Policy Analysis and Management, 16, 48-66.

Rahm, D. (2011). Regulating hydraulic fracturing in shale gas plays: The case of Texas. Energy Policy, 39, 2974-2981.

Raimi, D \& Newell, R. (2014). Oil and gas revenue allocation for local governments in eight states. Duke University Energy Initiative. Retrieved November 11, 2014, from http://energy.duke.edu/sites/default/files/attachments/Oil\%20Gas\%20Revenue\%20Alloca tion\%20to\%20Local\%20Government\%20FINAL.pdf.

Rokosh, C.D., Pawlowicz, J.G., Berhane, H., Anderson, S.D.A., \& Beaton, A.P. (2009). What is shale gas? An introduction to shale-gas geology in Alberta. Energy Resources Conservation Board, Alberta Geological Survey. Retrieved October 10, 2013, from http://www.ags.gov.ab.ca/publications/ofr/pdf/ofr_2008_08.pdf.

Rosenbaum, P.R., \& Rubin, D.B. (1983). The central role of the propensity score in observational studies for causal effects. Biometrika, 70, 45-55.

Sanders, N.J. (2012). Toxic assets: How the housing market responds to environmental information shocks. College of William and Mary, Department of Economics Working Paper Number 128. Retrieved March 28, 2014, from http://economics.wm.edu/wp/cwm_wp128.pdf.

Santiago, A.M., Galster, G.C., \& Tatian, P. (2001). Assessing the property value impacts of the dispersed housing subsidy program in Denver. Journal of Policy Analysis and Management, 20, 65-88.

Schintler, L. \& Istrate, E. (2011). Tracking the housing bubble across metropolitan areas-spatio-temporal comparison of house price indices. Cityscape, 14, 165-182.

Schwartz, S.I. \& Zorn, P.M. (1988). A critique of quasiexperimental and statistical controls for measuring program effects: Application to urban growth control. Journal of Policy Analysis and Management, 7, 491-505.

S\&P/Case Shiller. (2014). S\&P Case-Shiller Home Prices Indices Methodology. Retrieved February 27, 2014, from http://www.spindices.com/index-family/real-estate/sp-caseshiller.

Texas Legislative Council. (2002). Overview of local taxes in Texas. Retrieved March 4, 2014, from http://www.tlc.state.tx.us/pubspol/localtaxes.pdf 
Texas Railroad Commission. (2015). Barnett shale information. Retrieved May 22, 2015, from http://www.rrc.state.tx.us/oil-gas/major-oil-gas-formations/barnett-shale-information/

Texas Taxpayers and Research Association (TTRA). 2012. An Introduction to School Finances in Texas. Revised January 2012. Available at http://www.ttara.org/files/document/file4f1732f763446.pdf.

Tiebout, C. M. (1956). A pure theory of local expenditures. Journal of Political Economy, 64, 416-424.

Timmins, C. \& Vissing, A. (2014). Shale gas leases: Is bargaining efficient and what are the implications for homeowners if it is not? Duke University, Working Paper. Retrieved December 11, 2014, from http://public.econ.duke.edu/ timmins/Timmins_Vissing_11_15.pdf.

Van der Ploeg, F. (2011). Natural resources: Curse or blessing? Journal of Economic Literature, 49, 366-420.

Wassmer, R.W. (1993). Property taxation, property base, and property value: An empirical test of the "New View." National Tax Journal, 46, 135-159.

Weber, J.G. (2012). The effects of a natural gas boom on employment and income in Colorado, Texas, and Wyoming. Energy Economics, 34, 1580-1588.

Weber, J.G. (2014). A decade of natural gas development: The makings of a resource curse? Resource and Energy Economics, 37, 168-183.

Weber, J.G., \& Hitaj, C. (2015). What can we learn about shale gas development from land values? Opportunities, challenges, and evidence from Texas and Pennsylvania. Agricultural and Resource Economics Review, 44, 40-58.

Winkler, A. (2013). The house price indices. Insights, American Action Forum. Retrieved February 27, 2014 from http://americanactionforum.org/insights/the-house-price-indices.

Zuckerman, G. (2013). The frackers: The outrageous inside story of the new billionaire wildcatters. New York: Penguin Group. 


\section{Acknowledgements}

We thank Camille Salama, Amanda Harker, Elaine Hill, Tara Mathews, Sara Melo de Weber, and Max Harleman for their comments and assistance.

\section{APPENDIX}

\section{Zillow Housing Value Index}

The Zillow Housing Value Index (ZHVI) is robust to the changing mix of properties that sell in different periods because it involves estimating a sale price for every home. By incorporating the values of all homes in an area-not just those homes that sold-it avoids the bias associated with median sale prices (Dorsey et al., 2010). Unlike the ZHVI, the S\&P/Case-Shiller Home Price Index only uses information from repeat-sales properties and is value weighted, giving trends among more expensive homes greater influence on overall estimated price changes (S\&P/Case Shiller, 2014; Winkler, 2013). The S\&P/C-S index, nonetheless, is widely used. In the aggregate the ZHVI and the S\&P/C-S index track closely, with a Pearson correlation coefficient of 0.95 and median absolute error of 1.5 percent (Humphies, 2008). Three other studies find similar results when comparing various versions of the two indexes, finding correlations of 0.92 or higher (Guerrieri et al, 2010; Schintler \& Istrate, 2011; Winkler, 2013). We compared the ZHVI for Dallas-Fort Worth with the corresponding S\&P/C-S index and found a correlation of 0.95.

\section{Public Finance Data}

The Texas Education Agency's Public Education Information Management System provides data on the property tax base and school revenues. Although the property tax base is reported at the school district level, it is the same base used by city and county governments in our study area. 
For example, if a county and school district perfectly overlap, they would have the same property tax base. School property tax rates came from the Texas Bond Review Board and are a percentage of a property's assessed value that is paid in annual property taxes. We allocated school district data to zip codes based on the percent of the zip code area in each district.

Districts and zip codes tended to line up well, with 79 percent of the average zip code's area lying in just one school district. 


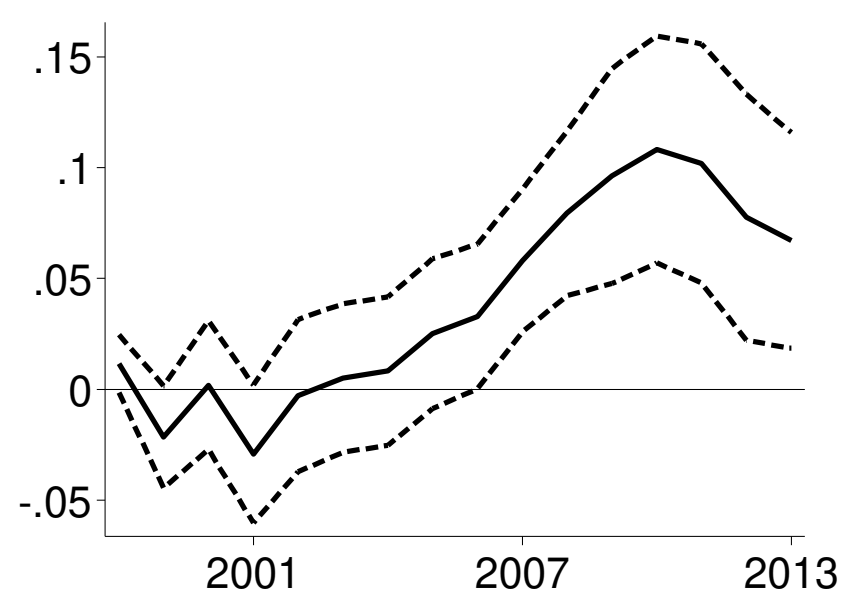

(a) $\log$

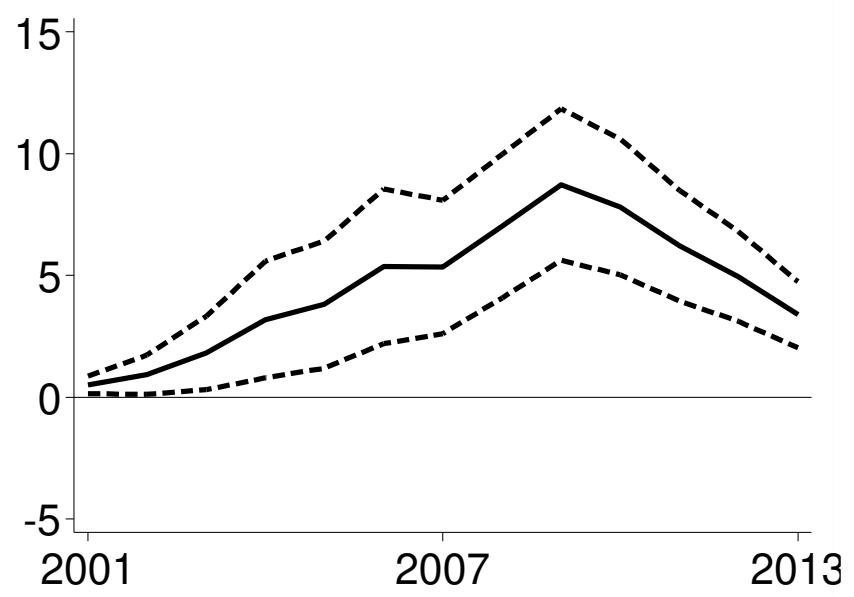

(c) Oil and Gas Tax Base

$(\$ 10,000 /$ student $)$

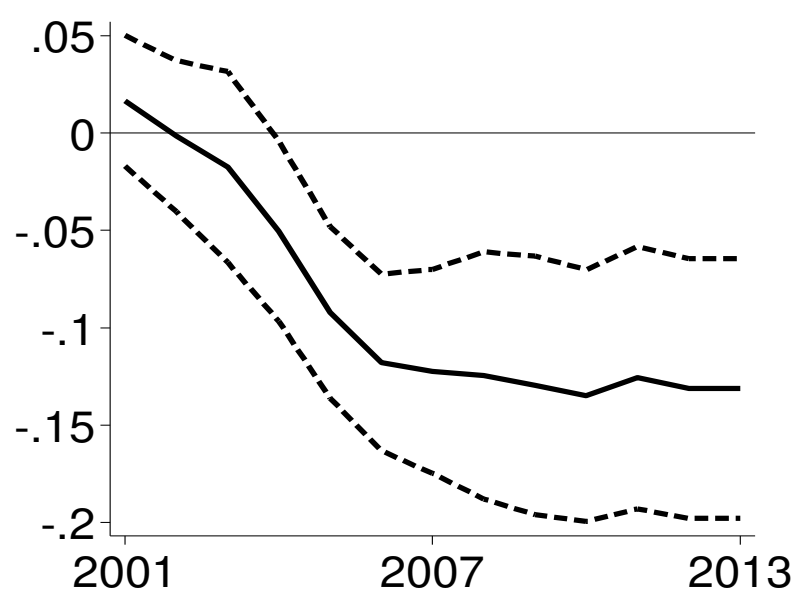

(e) Property Tax Rate (\%)

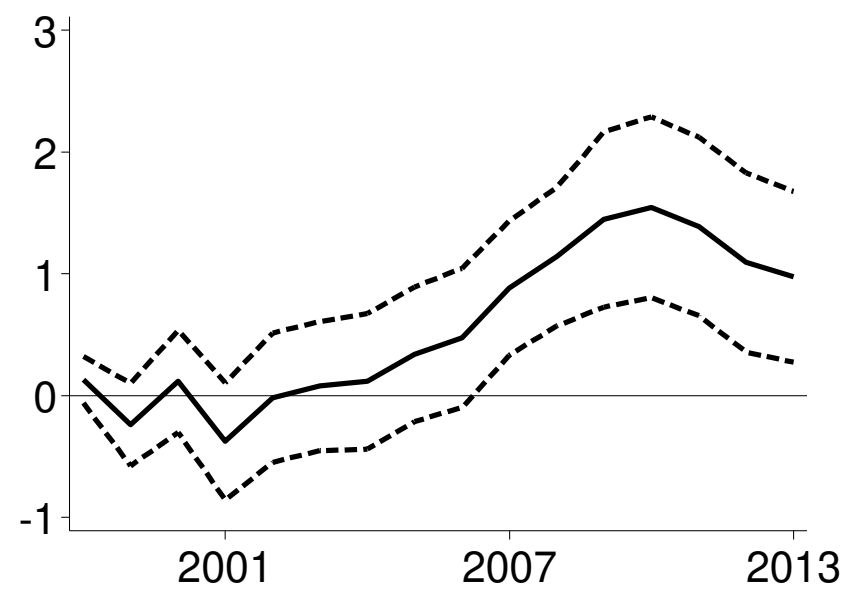

(b) ZHVI $(\$ 10,000)$

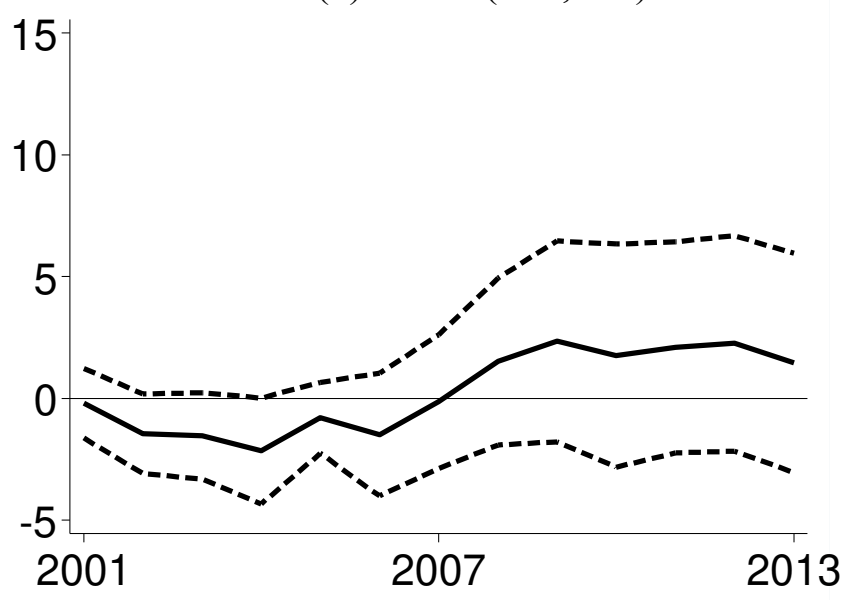

(d) Non-O\&G, Non-Residential Tax Base $(\$ 10,000$ /student $)$

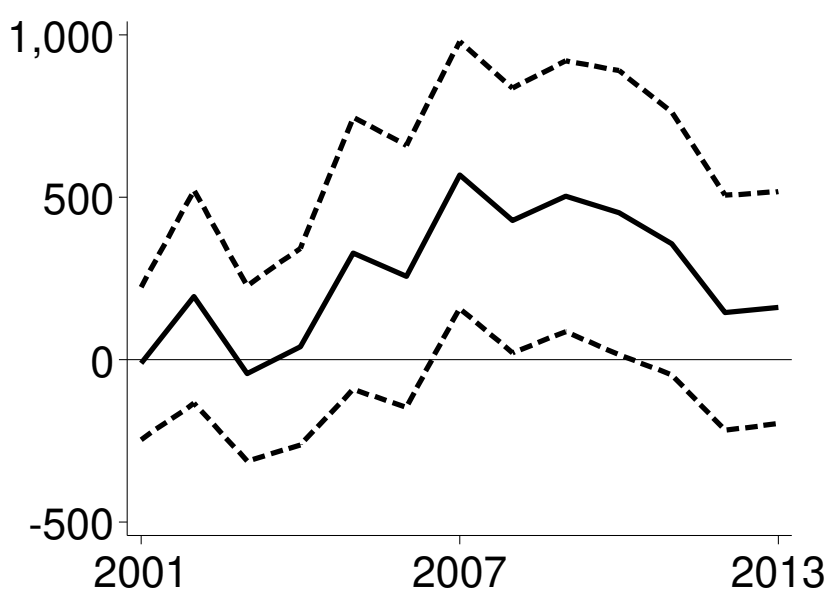

(f) School Revenues (\$/student)

Figure A1. The Change in Conditional Mean Differences Across Shale and Nonshale Zip Codes , Propensity- Score-Trimmed Sample

Note: The black line represents the coefficients on the interactions between the shale binary variable and the year binary variables estimated using equation (1). The dashed gray lines represent the $95 \%$ confidence intervals. The propensity-scoretrimmed sample includes 69 zip codes and is based on tri53ming the full sample using optimal cutoffs based on the estimated propensity to be a shale zip code based on socioeconomic characteristics as described in the text. 


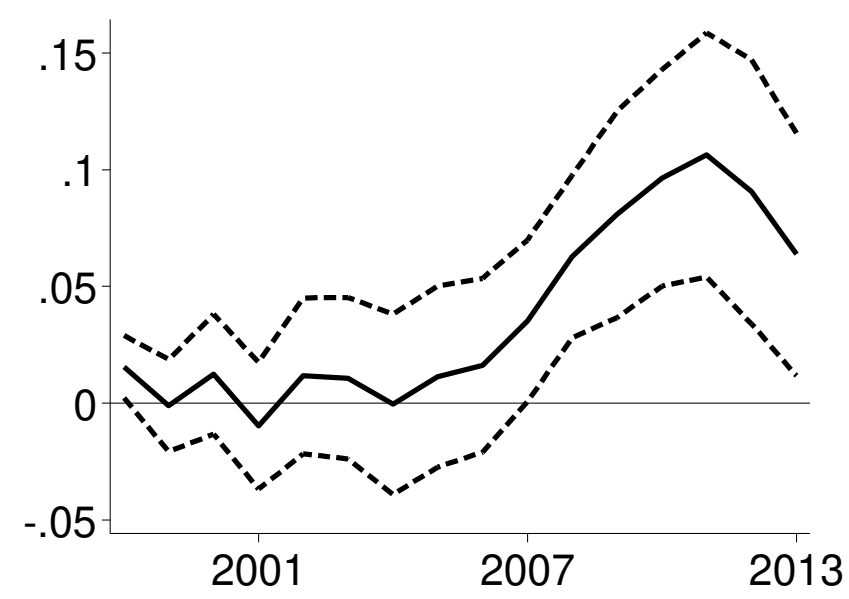

(a) $\log \mathrm{ZHVI}$

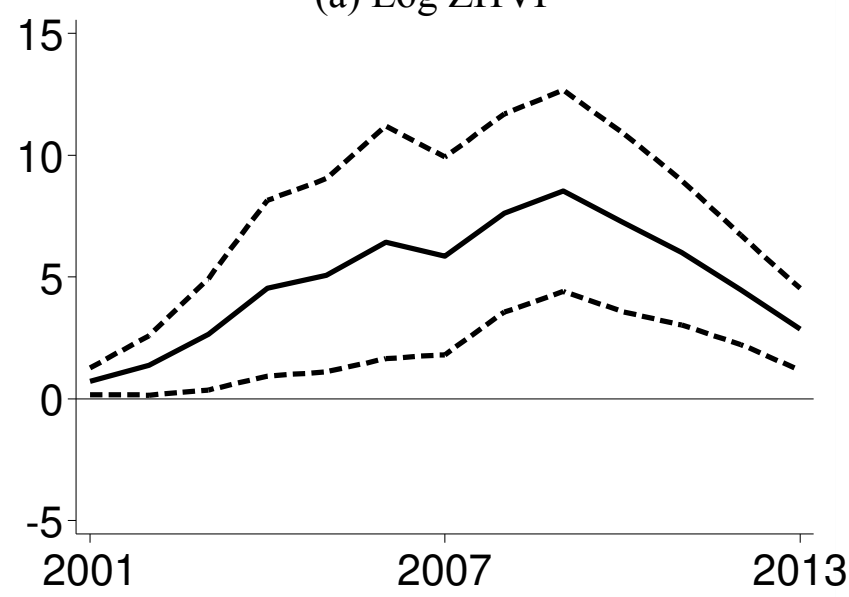

(c) Oil and Gas Tax Base

$(\$ 10,000$ /student $)$

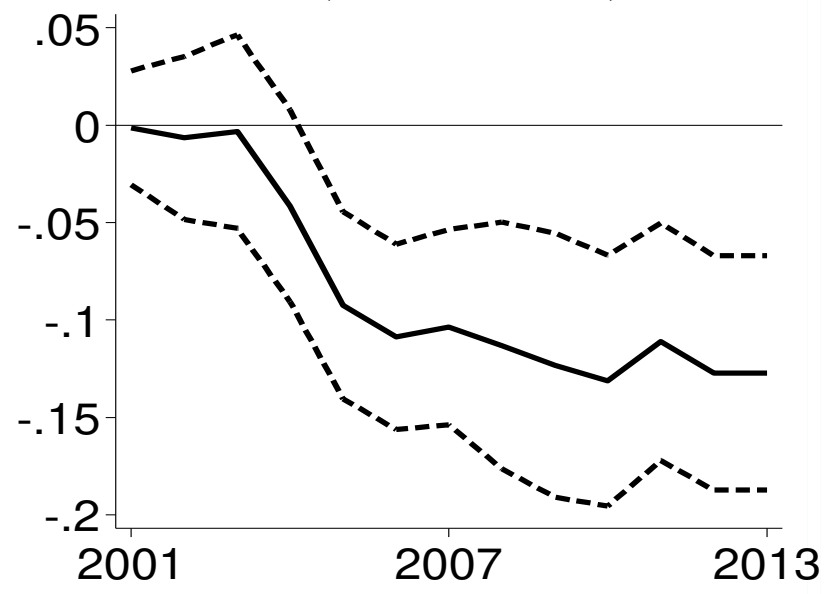

(e) Property Tax Rate (\%)

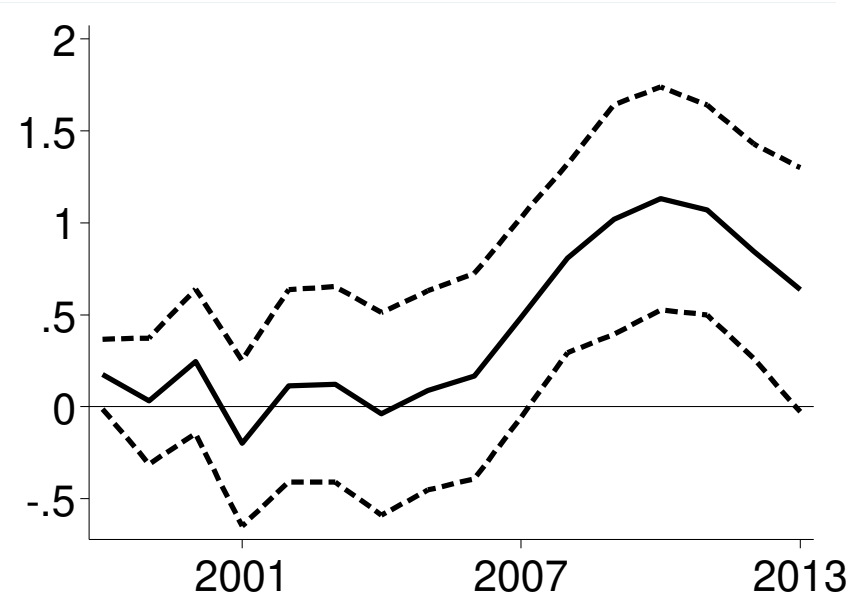

(b) ZHVI

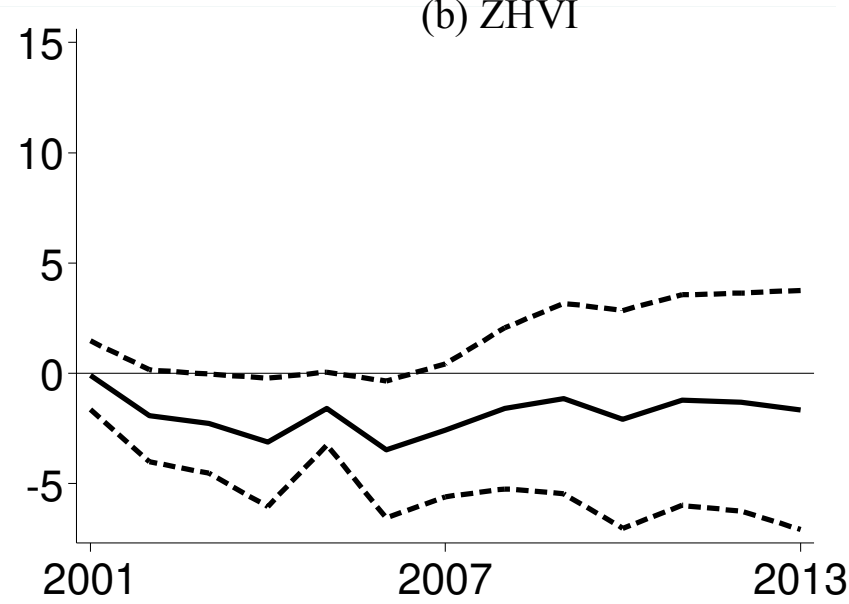

(d) Non-O\&G, Non-Residential Tax Base $(\$ 10,000$ /student $)$

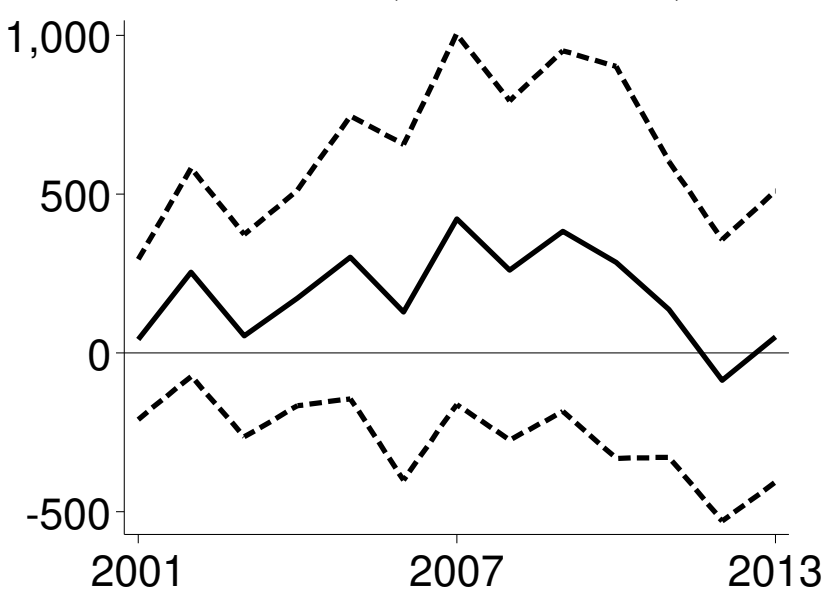

(f) School Revenues (\$/student)

Figure A2. The Change in Conditional Mean Differences Across Shale and Nonshale Zip Codes, Distance-Trimmed Sample

Note: The black line represents the coefficients on the interactions between the shale binary variable and the year binary variables estimated using equation (1). The dashed gray lines represent the $95 \%$ confidence intervals. The distance-trimmed sample is based on removing the 25 percent of zip codes in the full sample that were furthest from the eastern boundary of the Barnett Shale, which leaves 59 zip codes. 
Table A1. First-Stage regressions for the trimmed subsamples

Panel A: Annual Changes

$\Delta$ O\&G Tax Base (10,000/student)

\begin{tabular}{lcccc}
\hline Variables & \multicolumn{3}{c}{$\Delta$ Propensity-Score-Trimmed Sample } & Distance-Trimmed Sample \\
\hline (Thick_Depth) $\mathrm{x} \Delta \ln$ (Price), t-1 & $0.335^{* * *}$ & $0.291^{* * *}$ & $0.359^{* * *}$ & $0.320^{* * *}$ \\
& $(0.079)$ & $(0.066)$ & $(0.100)$ & $(0.084)$ \\
Wells drilled/sq. km, t, t-1 & & $1.970^{* * *}$ & & $2.101^{* * *}$ \\
& & $(0.393)$ & & $(0.427)$ \\
Cumulative wells drilled/sq. km, t-2 & & $-0.266^{* * *}$ & & $-0.304^{* * *}$ \\
& & $(0.055)$ & & $(0.056)$ \\
\hline F statistic on (Thick_Depth) x $\Delta \ln$ (Price) & 18.0 & 19.3 & 13.0 & 14.6 \\
Zip Codes & 69 & 69 & 59 & 59 \\
Observations & 828 & 828 & 708 & 708 \\
Adjusted R squared & 0.15 & 0.27 & 0.13 & 0.28 \\
\hline
\end{tabular}

Panel B: Change 2000-2013

$\Delta$ O\&G Tax Base (\$10,000/student)

\begin{tabular}{lcccc}
\hline Variables & Propensity-Score-Trimmed Sample & \multicolumn{2}{c}{ Distance-Trimmed Sample } \\
\hline (Thick_Depth) x $\Delta \ln$ (Price), 2000-2012 & $-6.741^{* * *}$ & $-3.032^{* *}$ & $-5.765^{* * *}$ & -1.880 \\
& $(1.536)$ & $(1.307)$ & $(1.740)$ & $(1.181)$ \\
Wells drilled/sq. km, 2012, 2013 & & -0.078 & & -2.339 \\
& & $(1.717)$ & & $(4.966)$ \\
Cumulative wells drilled/sq. km, 2011 & & $1.271^{* *}$ & & $1.408^{* * *}$ \\
& & $(0.539)$ & & $(0.511)$ \\
\hline F statistic on (Thick_Depth) x $\Delta \ln$ (Price) & 19.3 & 5.4 & 11.0 & 2.5 \\
Zip Codes & 69 & 69 & 59 & 59 \\
Observations & 69 & 69 & 59 & 59 \\
Adjusted R squared & 0.28 & 0.39 & 0.36 & 0.57 \\
\hline
\end{tabular}

Note: $* * *, * * *$ indicate statistical significance at the 1,5 , and 10 percent levels. The results in Panel A exploit annual variation over the 2000 to 2013 period. For these results, robust standard errors clustered by zip code are in parenthesis. Year dummy variables are included in the annual-based regression but excluded from the table. The results in Panel B are based on differencing 2000 values from 2013 values, thereby converting the panel into a cross section of zip codes. For these results, unclustered robust standard errors are in parenthesis. The propensity-score-trimmed sample is based on trimming the full sample using optimal 
cutoffs based on the estimated propensity to be a shale zip code based on socioeconomic characteristics as described in the text. The distance-trimmed sample is based on removing the 25 percent of zip codes in the full sample that were furthest from the eastern boundary of the Barnett Shale. 
Table A2. Employment in shale and nonshale counties, 2001-2013

\begin{tabular}{lcc}
\hline \hline & \multicolumn{2}{c}{ Ln(Emp) } \\
& All Counties & Excluding Tarrant and Dallas \\
\hline Shale & 0.004 & 0.002 \\
& $(0.007)$ & $(0.008)$ \\
Period 2009-2013 & $-0.019^{* *}$ & $-0.025^{* * *}$ \\
& $(0.008)$ & $(0.008)$ \\
Period x Shale & 0.008 & 0.010 \\
Intercept & $(0.012)$ & $(0.013)$ \\
& $0.030^{* * *}$ & $0.037 * * *$ \\
Observations & $(0.005)$ & $(0.006)$ \\
Adjusted R-squared & 143 & 117 \\
\hline
\end{tabular}

Note: $* * *, * * *$ indicate statistical significance at the 1,5, and 10 percent levels. Robust standard errors are in parenthesis. Shale counties are Denton, Hood, Johnson, Parker, and Tarrant. Nonshale counties are Dallas, Collin, Ellis, Hunt, Kaufman, and Rockwall. 
Table A3. Construction trends in shale and nonshale counties

\begin{tabular}{lcc}
\hline & Ln(Permitted Buildings) & Ln(Permitted Units) \\
\hline Shale & -283 & -729 \\
& $(880)$ & $(1,146)$ \\
Period 2009-2013 & $-1,910^{* * * *}$ & $-1,944^{*}$ \\
& $(664)$ & $(1,058)$ \\
Period x Shale & 134 & 14 \\
& $(1,006)$ & $(1,436)$ \\
Intercept & $3,468^{* * *}$ & $4,715^{* * *}$ \\
& $(568)$ & $(787)$ \\
\hline Observations & 154 & 154 \\
Adjusted R-squared & 0.040 & 0.020 \\
\hline
\end{tabular}

Note: $* * *, * *, *$ indicate statistical significance at the 1,5, and 10 percent levels. Robust standard errors are in parenthesis. Shale counties are Denton, Hood, Johnson, Parker, and Tarrant. Nonshale counties are Dallas, Collin, Ellis, Hunt, Kaufman, and Rockwall. 